\title{
EXPRESSION OF PROTEASE-ACTIVATED RECEPTORS (PARS) IN OLN-93 OLIGODENDROGLIAL CELLS AND MECHANISM OF PAR-1- INDUCED CALCIUM SIGNALING
}

\author{
Y. WANG, ${ }^{a}$ C. RICHTER-LANDSBERG ${ }^{b}$ AND \\ G. REISER ${ }^{a *}$ \\ ${ }^{a}$ Otto-von-Guericke-Universität Magdeburg, Medizinische Fakultät, In- \\ stitut für Neurobiochemie, Leipziger Straße 44, 39120 Magdeburg, \\ Germany \\ ${ }^{b}$ Molekulare Neurobiologie, Universität Oldenburg, 26111 Oldenburg, \\ Germany
}

\begin{abstract}
Protease-activated receptors (PARs) are a group of four members of the superfamily of $G$ protein-coupled receptors that transduce cell signaling by proteolytic activity of extracellular serine proteases, such as thrombin. Possible expression and functions of PARs in oligodendrocytes, the myelin forming cells of the CNS, are still unclear. Here, the oligodendrocyte cell line OLN-93 was used to investigate the signaling of PARs. By reverse transcription-polymerase chain reaction (RT-PCR), immunostaining and $\mathrm{Ca}^{2+}$ imaging studies, we demonstrate that OLN-93 cells functionally express PAR-1. PAR-3 seems to be expressed without apparent activity, and PAR-2 and PAR-4 cannot be detected. Shortterm stimulation of the OLN-93 cells with PAR-1 agonists, such as thrombin, trypsin and PAR-1 activating peptide, dose-dependently induced a transient rise of $\left[\mathrm{Ca}^{2+}\right]_{\mathrm{i}}$. Concentration-effect curves display a sigmoidal concentration dependence. Elevation of $\left[\mathrm{Ca}^{2+}\right]_{i}$ induced by PAR-1 mainly resulted from $\mathrm{Ca}^{2+}$ release from intracellular stores. Studies on the effects of pertussis toxin (PTX), phospholipase $C$ antagonist and 2-APB, showed that in OLN-93 cells (i) the calcium signaling cascade from PAR-1 was mediated through PTX-insensitive G proteins, (ii) activation of phospholipase $\mathrm{C}$ and liberation of Ins $\mathrm{P}_{3}$ were events upstream of the $\mathrm{Ca}^{2+}$ release from the stores. In addition, the present study analyzed PAR-1 desensitization caused by exposure to thrombin, trypsin, and PAR-1 activating peptide, elucidated the influence of the protease cathepsin G on PAR-1 activation, and also characterized PAR-1 desensitization. This is the first study, which shows that OLN-93 oligodendrocytes functionally express PAR-1, and identifies the receptor cou-
\end{abstract}

*Corresponding author. Tel: +49-391-671-3088; fax: +49-391-671-3097. E-mail address: georg.reiser@medizin.uni-magdeburg.de (G. Reiser). Abbreviations: AP, activating peptide; bp, base pair; CNP, 2', 3'-cyclic nucleotide 3'-phosphodiesterase; DMEM, Dulbecco's Modified Eagle medium; GAPDH, glyceraldehyde phosphate dehydrogenase; GYPGKF, H-Gly-Tyr-Pro-Gly-Lys-Phe-OH, (mouse protease-activated receptor-4 activating peptide); HBS, HEPES-buffered saline; IL, interleukin; InsP $\mathrm{P}_{3}$, inositol 1,4,5-trisphosphate; PARs, proteaseactivated receptors; PLC, phospholipase C; PTX, pertussis toxin; RT-PCR, reverse transcription-polymerase chain reaction; SLIGRL, $\mathrm{H}$-Ser-Leu-lle-Gly-Arg-Leu-OH (rat PAR-2 activating peptide); TFRGAP, H-Thr-Phe-Arg-Gly-Ala-Pro-OH (human PAR-3 activating peptide); TRag, Ala-pFluoro-Phe-Arg-Cha-HomoArg-Tyr- $\mathrm{NH}_{2}$ (synthetic thrombin receptor agonist peptide); U73122, phospholipase C antagonist; U73343, inactive analog of U73122; YFLLRNP, $\alpha$-thrombin (protease-activated receptor-1) antagonist peptide; 2-APB, 2aminoethoxydiphenylborate (non-competitive $\mathrm{InsP}_{3}$ receptor antagonist). pling to mobilization of intracellular calcium. Moreover, the expression of PAR-1 was demonstrated by RT-PCR in primary oligodendrocytes from rat brain. (c) 2004 IBRO. Published by Elsevier Ltd. All rights reserved.

Key words: thrombin, trypsin, protease-activated receptors, calcium signaling, cathepsin $\mathbf{G}$.

Thrombin, a glycosylated trypsin-like serine protease, is formed from prothrombin, which is mainly synthesized by the liver and secreted into the bloodstream. Previous data showed that thrombin might be produced locally in the brain (Dihanich et al., 1991). Thrombin level are upregulated in the CNS after brain injury, such as a primary intracerebral hemorrhage and brain trauma (Xi et al., 2003). After global cerebral ischemia prothrombin mRNA has been found to increase (Riek-Burchardt et al., 2002). Till now the normal physiological role for thrombin in the CNS is unknown, but some studies have shown that thrombin, at low concentration acting on thrombin receptors (protease-activated receptors, PARs), induces neuroprotection in ischemic and hemorrhagic injury and at high concentration causes brain damage (Striggow et al., 2000; $\mathrm{Xi}$ et al., 2003). Some recent data showed that thrombin by activating PAR-1 induced neurodegeneration of dopaminergic neurons in the substantia nigra (Carreno-Muller et al., 2003) and of neurons affected by focal ischemic situation (Junge et al., 2003). Moreover, a considerable number of studies have demonstrated that thrombin is an important pathophysiological modulator of the inflammatory response in the brain (refs. in Boven et al., 2003; Wang and Reiser, 2003). Meanwhile, accumulating evidence has also indicated that thrombin and its receptors trigger protective or apoptotic effects on neurons and glial cells. All these results underline the importance of thrombin in regulating pathophysiological processes in the CNS.

PARs belong to the superfamily of $G$ protein-coupled receptors. To date, four members of the PAR family have been identified. PAR-1, PAR-3 and PAR-4 are thrombin receptors; trypsin, as agonist of PAR-2, can activate PAR-1 and PAR-4 (Ishihara et al., 1997; Wang et al., 2002a; Xu et al., 1998). Activation of PARs is initiated through proteolytic cleavage of the extracellular $\mathrm{N}$-terminus of the receptor. This results in the generation of a new $\mathrm{N}$-terminal peptide which as a tethered ligand interacts with extracellular loop-2 of the receptor to induce intracellular signal transduction (Macfarlane et al., 2001; Wang and Reiser, 2003). PARs are expressed in many tissues by a wide variety of cells, such as endothelial cells, platelets, fibroblasts, smooth muscle cells, 
monocytes, osteoblasts, neurons, glia, and mast cells (Dihanich et al., 1991; Nishikawa et al., 2000; Strukova, 2001), where they are involved in several physiological and pathological processes, including growth and development, mitogenesis and inflammation. Our previous studies have shown that rat astrocytes in primary cultures functionally express all four types of PARs (Ubl et al., 1998; Wang et al., 2002a). Thus, the roles of PARs in astrocytes are well established (Wang and Reiser, 2003).

Oligodendrocytes, as major glial cells in brain, are mainly responsible for the formation of myelin in the CNS. As recently suggested, oligodendrocytes can also provide trophic support for neuronal survival and function and may complement astrocytes in this ability (Du and Dreyfus, 2002). In addition, oligodendrocytes are vulnerable to various insults and their damage strongly affects brain functions (Levine et al., 2001). Thus, oligodendrocytes might play an important role in inflammatory diseases such as multiple sclerosis (Lassmann, 1998) and other demyelinating/hypomyelinating disorders (Vela et al., 1998).

Several studies indicate that PARs are instrumental in inflammation (Cirino et al., 1996; Fiorucci and Distrutti, 2002; Seeliger et al., 2003; Vergnolle et al., 1999a; Vergnolle et al., 1999b). The activation of PARs can induce inflammatory mediators, such as interleukin (IL)-6, IL-8 and prostaglandin $E_{2}$, and their release from human respiratory epithelial cells (Asokananthan et al., 2002). The activation of PARs can also result in a rise in the intracellular $\mathrm{Ca}^{2+}$ concentration in different types of cells, such as rat astrocytes, C6 glioma cells, human respiratory epithelial cells, human platelets and endothelial cells, human bronchial epithelial cells, and human airway smooth muscle cells (Asokananthan et al., 2002; Berger et al., 2001; Molino et al., 1995; Ubl et al., 1998, 2002). The $\left[\mathrm{Ca}^{2+}\right]_{i}$ response is characterized by two distinct phases, firstly a fast, transient rise corresponding to the release of $\mathrm{Ca}^{2+}$ from intracellular stores and secondly, a sustained increase due to entry of $\mathrm{Ca}^{2+}$ across the plasmalemma. Each phase, $\mathrm{Ca}^{2+}$ release and entry, can regulate discrete cellular functions (Moore et al., 1998).

Calcium, an important second messenger, has been shown to play a role in the regulation of proliferation, invasion and metastatic potential in tumor cells (Cole and Kohn, 1994). Moreover, calcium-mediated signaling is one of the mechanisms by which CNS cells communicate with each other and modulate the activity of adjacent cells (Pasti et al., 1997). Presence and possible functions of PARs in oligodendrocytes are still unclear. The present study is the first report about the expression of PARs in oligodendrocytes. OLN-93, a permanent oligodendroglia cell line derived at later stage of differentiation from spontaneously transformed cells in primary rat brain glial cultures, resembles primary cultured oligodendrocytes in its antigenic and morphological properties (RichterLandsberg and Heinrich, 1996). These cells show characteristics of immature oligodendrocytes and provide a useful model system to study oligodendrocyte functions. The PAR-1-induced calcium signaling pathways were studied here in OLN-93 cells. Moreover, the expression of PAR-1

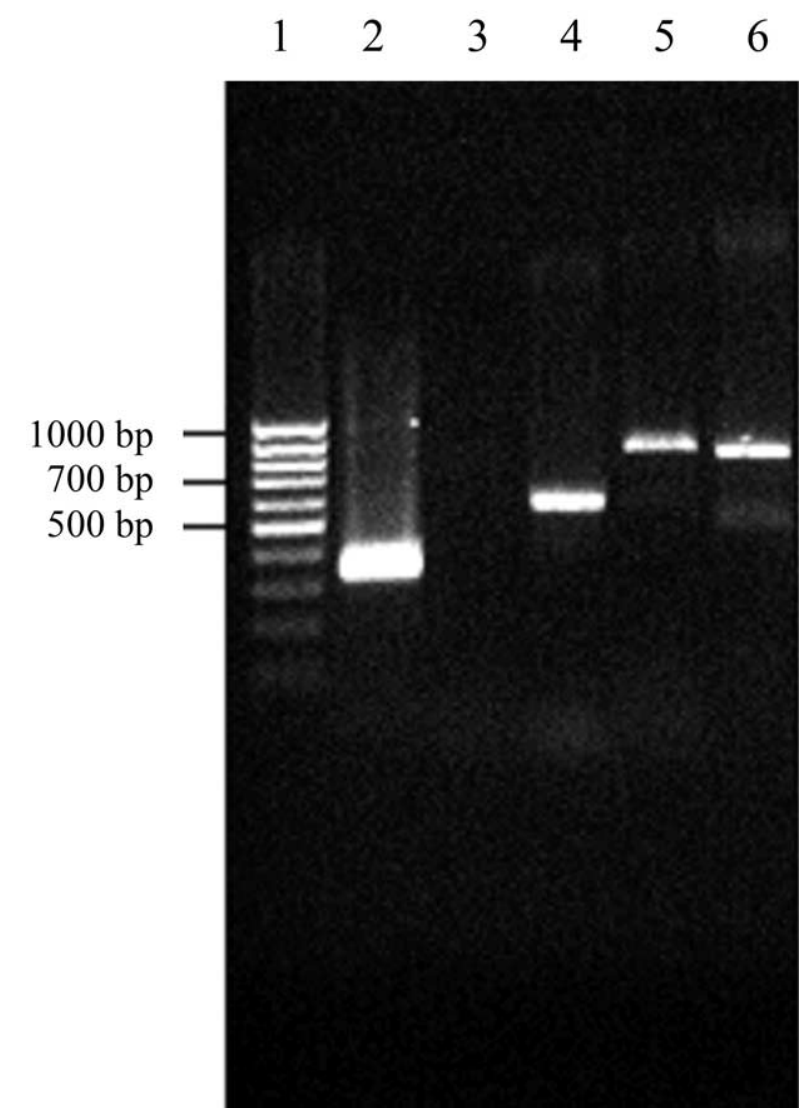

Fig. 1. Detection of PAR-1, PAR-2, PAR-3 and PAR-4 in OLN-93 cells by RT-PCR. One microgram of RNA was reverse-transcribed, and the resulting cDNA was amplified by PCR for 35 reaction cycles as described in Experimental Procedures. OLN-93 cells mainly express PAR-1 and PAR-3, but not PAR-2 and PAR-4. Lane 1 represents a DNA size standard, as indicated. Lanes 2-6 are PCR products using primers for PAR-1, PAR-2, PAR-3, PAR-4 and GAPDH, respectively. The PCR product obtained with the PAR-4 primers (lane 5) is due to genomic DNA, because the 854 bp fragment contains a 295 bp intron (for detail see text). The PCR experiments were repeated at least three times with three different preparations giving identical results.

was found by reverse transcription-polymerase chain reaction (RT-PCR) in primary oligodendrocytes from rat brain.

\section{EXPERIMENTAL PROCEDURES}

\section{Materials}

Human thrombin $(1 \mathrm{U} / \mathrm{ml}=15 \mathrm{nM})$ and human cathepsin $\mathrm{G}$ were purchased from Sigma (Deisenhofen, Germany), trypsin from Boehringer (Mannheim, Germany). The synthetic thrombin receptor agonist peptide (TRag, Ala-pFluoro-Phe-Arg-Cha-HomoArgTyr- $\mathrm{NH}_{2}$ ), rat PAR-2 activating peptide (AP; SLIGRL, Ser-Leu-IleGly-Arg-Leu), mouse PAR-4 AP (GYPGKF, Gly-Tyr-Pro-Gly-LysPhe) and the PAR-1 antagonist peptide (YFLLRNP) were purchased from Neosystem Laboratoire (Strasbourg, France). Human PAR-3 AP (TFRGAP, H-Thr-Phe-Arg-Gly-Ala-Pro-OH) was from Bachem (Heidelberg, Germany). Pertussis toxin (PTX), U73122, U73343 and 2-aminoethoxydiphenylborate (2-APB) were obtained from Calbiochem (La Jolla, CA, USA). Goat polyclonal antibodies against PAR-1 (C-18), PAR-2 (C-17), PAR-3 (M-20) and PAR-4 (S-20) were purchased from Santa Cruz (Heidelberg, 


\section{$6 \mathrm{~h} \quad 1 \mathrm{~d} \quad 5 \mathrm{~d} \quad 7 \mathrm{~d} \quad 12 \mathrm{~d}$} GAPDH

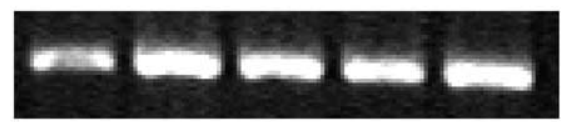

PAR-1

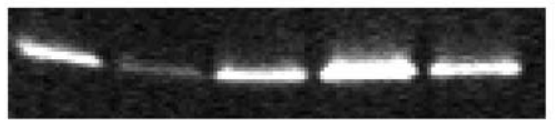

PAR-2

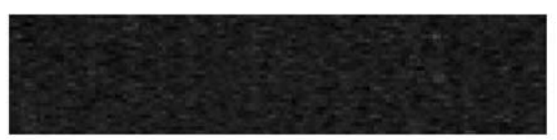

PAR-3

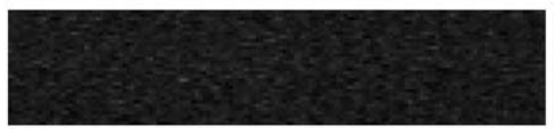

PAR-4

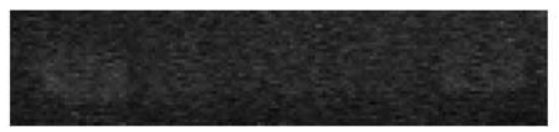

Fig. 2. Expression of PARs in primary rat oligodendrocytes cultured for different periods of time by RT-PCR. RNA isolated from primary oligodendrocytes at various times of differentiation ( $6 \mathrm{~h}, 1$ day, 5 days, 7 days and 12 days) was reverse-transcribed and the resulting cDNA was used as templates to check PAR-1, PAR-2, PAR-3 and PAR-4 expression. Primary oligodendrocytes express PAR-1. The PCR experiments were repeated at least three times with two different preparations giving identical results.

Germany). mAb-46-1 (mouse monoclonal antibody against myelin protein CNP $\left(2^{\prime}, 3^{\prime}\right.$-cyclic nucleotide $3^{\prime}$-phosphodiesterase)) was prepared by our laboratory (Reiser et al., 1994). Alexa 488 rabbit anti-mouse IgG antibody, Alexa 555 donkey anti-goat IgG antibody and Fura-2/AM were from Molecular Probes (Eugene, OR, USA). The cell culture medium was from GIBCO/BRL (Eggenstein, Germany) except for fetal calf serum, penicillin and streptomycin which were from Biochrom (Berlin, Germany).

\section{Cell culture}

Oligodendroglial cultures were prepared from the flasks after 6-8 days as previously described (Richter-Landsberg and Vollgraf, 1998). Briefly, O-2A progenitors, growing on the astrocytic cell layer, were separated by vigorous shaking (for $16 \mathrm{~h}$ at 240 r.p.m.) and taken off. Precursor cells were replated on poly-L-lysinecoated culture dishes $\left(3 \times 10^{6}\right.$ cells $/ 10-\mathrm{cm}$ dish) and kept for 7 up to 12 days in serum-free Dulbecco's Modified Eagle medium (DMEM) to which insulin $(5 \mu \mathrm{g} / \mathrm{ml})$, transferrin $(5 \mu \mathrm{g} / \mathrm{ml})$, and sodium selenite $(5 \mathrm{ng} / \mathrm{ml}$; Boehringer) was added. Cells were cultured at $37{ }^{\circ} \mathrm{C}$ in a $\mathrm{CO}_{2}$ atmosphere. Growth medium was changed twice a week.

The OLN-93 cell line was derived from rat brain glial cultures (Richter-Landsberg and Heinrich, 1996). OLN-93 cells were grown in DMEM containing $10 \%$ heat-inactivated fetal calf serum, $50 \mathrm{U} / \mathrm{ml}$ penicillin and $50 \mu \mathrm{g} / \mathrm{ml}$ streptomycin at $37^{\circ} \mathrm{C}$ and $10 \%$ $\mathrm{CO}_{2}$.

\section{RNA isolation and RT-PCR}

Total RNA was isolated from cultured OLN-93 cells or cultured primary oligodendrocytes with RNeasy mini kit from Qiagen (Hilden, Germany). One microgram of RNA was reversetranscribed using Omniscript RT kit, and the resulting CDNA was amplified by PCR for 35 reaction cycles using HotStarTaq Master Mix kit. The primers used were as follows: PAR-1, forward $5^{\prime}$
CCTATGAGACAGCCAGAATC 3', reverse 5' GCTTCTTGACCTTCATCC 3 '; PAR-2, forward 5' GCGTGGCTGCTGGGAGGTATC 3', reverse 5' GGAACAGAAAGACTCCAATG 3'; PAR-3, forward $5^{\prime}$ GTGTCTCTGCACACTTAGTG $3^{\prime}$, reverse 5' ATAGCACAATACATGTTGCC 3'; PAR-4, forward 5' GGAATGCCAGACGCCCAGCATC 3', reverse 5' GGTGAGGCGTTGACCACGCA 3'; glyceraldehyde phosphate dehydrogenase (GAPDH), as a control, forward 5' GTGAAGGTCGGTGTCAAC 3', reverse 5' CAACCTGGTCCTCAGTGTAGC 3'. PCR cycles were performed as follows: denaturation at $95{ }^{\circ} \mathrm{C}$ for $15 \mathrm{~min}$; then denaturation at $94{ }^{\circ} \mathrm{C}$ for $60 \mathrm{~s}$, annealing at $51^{\circ} \mathrm{C}$ (GAPDH), $55^{\circ} \mathrm{C}$ (PAR-1 and PAR-3), $59^{\circ} \mathrm{C}$ (PAR-2) or $64^{\circ} \mathrm{C}$ (PAR-4) for $90 \mathrm{~s}$, and extension at $72{ }^{\circ} \mathrm{C}$ for $30 \mathrm{~s}$ for 35 cycles; finally additional extension at $72{ }^{\circ} \mathrm{C}$ for $10 \mathrm{~min}$.

\section{Detection of PARs by immunofluorescence}

OLN-93 cells were cultured on poly-L-lysine-coated glass coverslips. After washing with PBS, cells were fixed with $4 \%$ paraformaldehyde for 20 min at room temperature. For intracellular staining paraformaldehyde-fixed cells were pretreated with $0.2 \%$ Triton $\mathrm{X}-100$ in PBS containing 3\% BSA for $60 \mathrm{~min}$. Thereafter, cells were incubated with first antibody against PARs $(30 \mu \mathrm{g} / \mathrm{ml})$ and CNPase $(18 \mu \mathrm{g} / \mathrm{ml})$ for $120 \mathrm{~min}$. After washing, cells were incubated with the second antibody (Alexa 488 rabbit anti-mouse IgG antibody and Alexa 555 donkey anti-goat IgG antibody, $20 \mu \mathrm{g} / \mathrm{ml}$ ) for $120 \mathrm{~min}$. After further washing, coverslips were fixed and mounted with Aquatex. To check the specificity, the antibodies against PAR-1, PAR-2, PAR-3 and PAR- 4 were preincubated with antigen blocking peptides specific for each antibody at room temperature for $2 \mathrm{~h}$ in a five-fold (by weight) excess of antigen to antibody. Whole mounts were examined with a LSM510 confocal laser scanning microscope (Carl Zeiss, Jena, Germany).

\section{Cytosolic calcium measurement}

The free intracellular $\mathrm{Ca}^{2+}$ concentration $\left(\left[\mathrm{Ca}^{2+}\right]_{\mathrm{i}}\right)$ was determined using the $\mathrm{Ca}^{2+}$ sensitive fluorescent dye Fura-2/AM. For dye loading the cells grown on a coverslip were removed from the culture dish and placed in $1 \mathrm{ml} \mathrm{HEPES}$-buffered saline (HBS) for 30 min at $37^{\circ} \mathrm{C}$, supplemented with $2 \mu \mathrm{M}$ Fura-2/AM. The components of $\mathrm{HBS}$ are as follows (in $\mathrm{mM}$ ): $\mathrm{NaCl} 145, \mathrm{KCl} 5.4, \mathrm{MgCl}_{2}$ 1.8, glucose 25, HEPES 20, pH 7.4 adjusted with Tris (hydroxymethyl) aminomethane. Loaded cells were transferred into a perfusion chamber with a bath volume of about $0.2 \mathrm{ml}$ and mounted on an inverted microscope (Zeiss; Axiovert 135). During the experiments the cells were continuously superfused with medium heated to $37^{\circ} \mathrm{C}$.

Single-cell fluorescence measurements of $\left[\mathrm{Ca}^{2+}\right]_{i}$ were performed using an imaging system from TILL Photonics $\mathrm{GmbH}$ (Munich, Germany). Cells were excited alternately at $340 \mathrm{~nm}$ and $380 \mathrm{~nm}$ for $30-100 \mathrm{~ms}$ at each wavelength with a rate of $0.33 \mathrm{~Hz}$ and the resultant emission was collected at $>510 \mathrm{~nm}$. Images were stored on a personal computer; the changes in fluorescence ratio $\left(F_{340 \mathrm{~nm}} / \mathrm{F}_{380 \mathrm{~nm}}\right)$ were subsequently determined from selected regions of interest covering single OLN-93 cell.

\section{Statistical analysis}

Statistical evaluation was carried out using Student's $t$-test and Dunnett's multiple comparison test, and $P<0.05$ was considered significant. Data are given as means \pm S.E.M.

\section{RESULTS}

\section{RT-PCR detection of PARs in oligodendrocytes}

To identify mRNA encoding PARs, mRNA was extracted, reverse transcribed and the resulting CDNA was subjected 

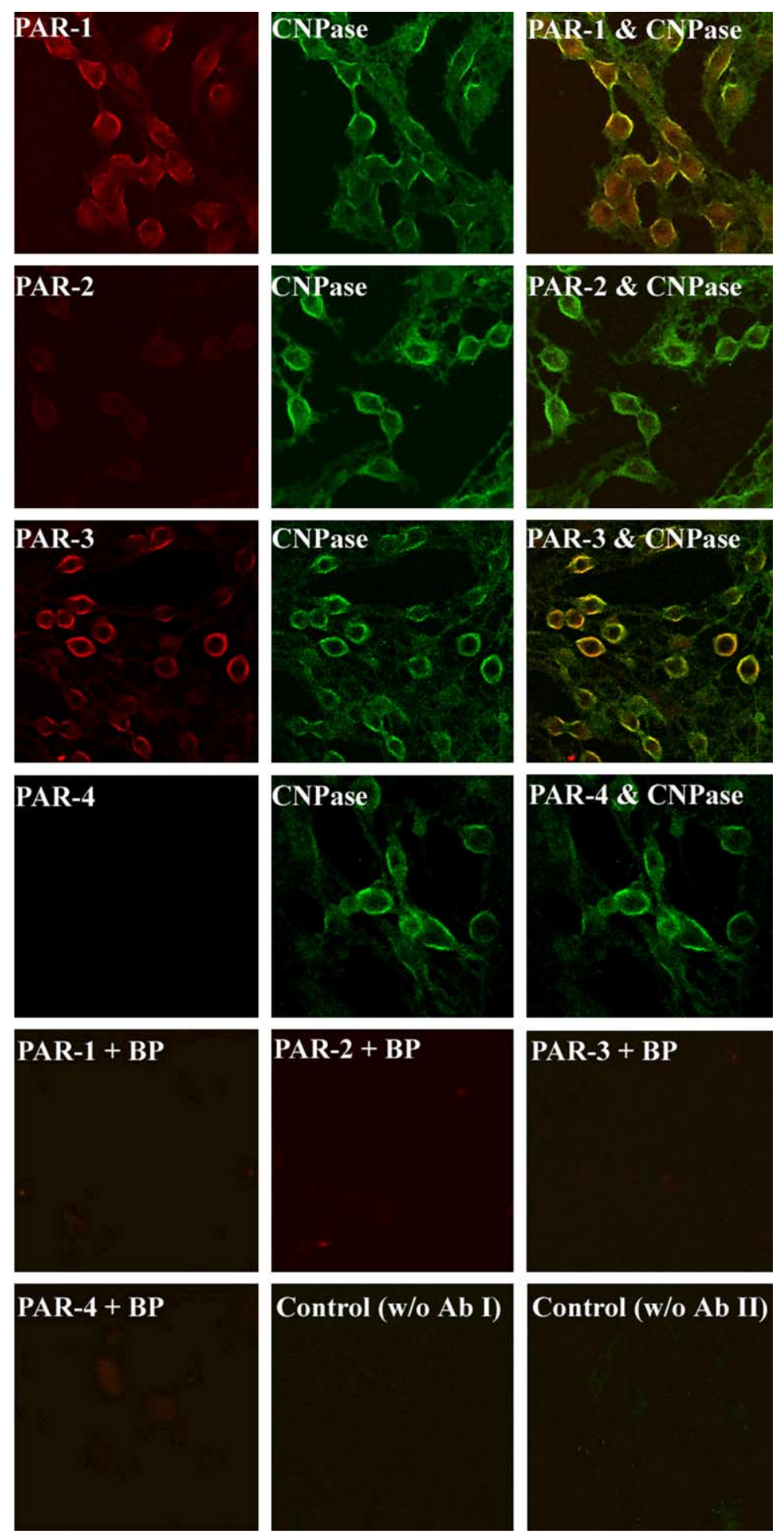

Fig. 3. Characterizations of indirect immunofluorescence staining for presence of PAR-1, PAR-2, PAR-3 and PAR-4 together with oligodendrocyte protein marker CNPase in OLN-93 cells. OLN-93 cells were double stained with respective PAR-1 (C-18), PAR-2 (C-17), PAR-3 (M-20), PAR-4 (S-20) antibody and CNPase antibody, as indicated by the respective labels. PAR-1 and PAR-3 were clearly colocalized with CNPase on the plasma membrane, while PAR-2 and PAR-4 were not expressed. The bottom two rows represent control experiments: the immunostaining can be blocked by preincubation with the respective blocking peptide (BP); further controls omitting primary antibody (without Ab I) or secondary antibody (without Ab II) are given. The experiments were repeated at least three times with three different preparations.

to RT-PCR. We used specific primers to amplify PAR-1, PAR-2, PAR-3 and PAR-4 cDNA from OLN-93 cells. Glyc- eraldehyde phosphate dehydrogenase (GAPDH, 835 base pairs [bp]) was taken as control for the RT-PCR conditions. 
A

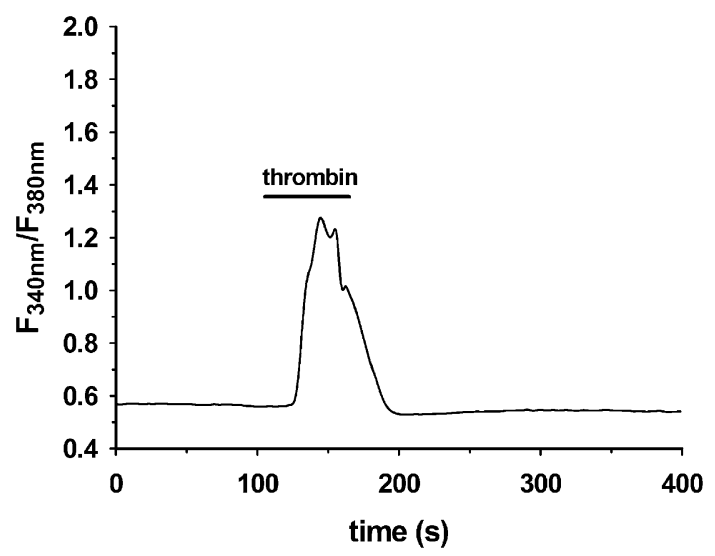

C

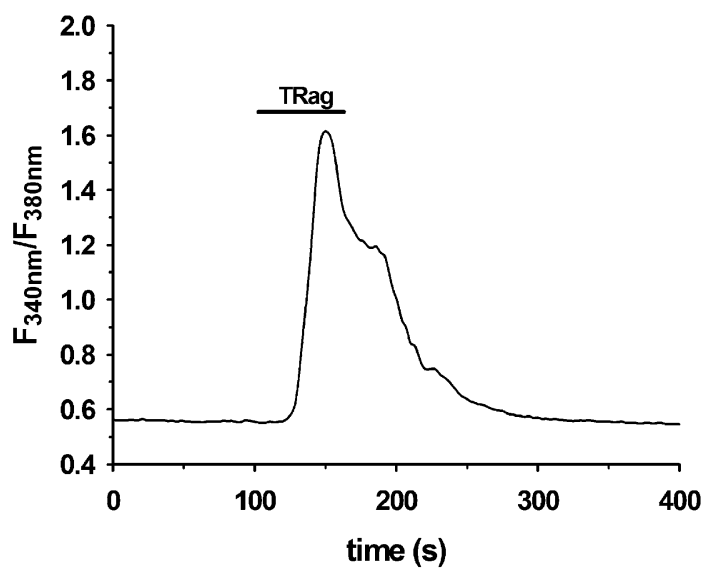

$\mathbf{E}$

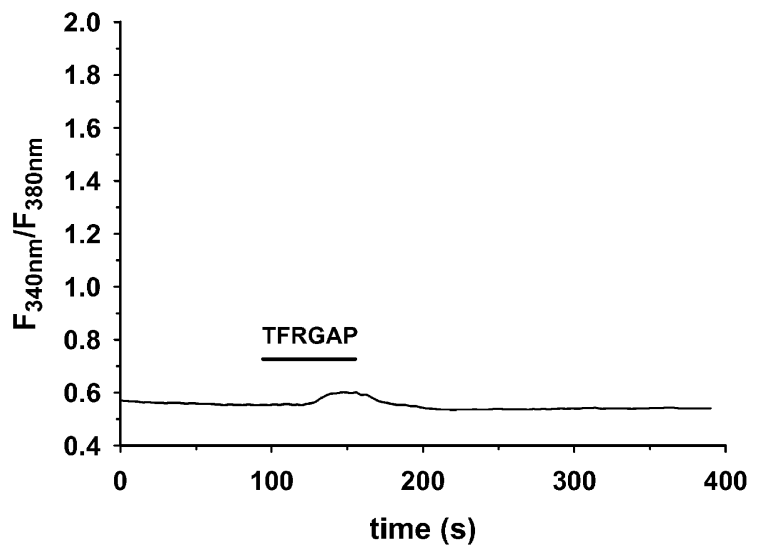

B

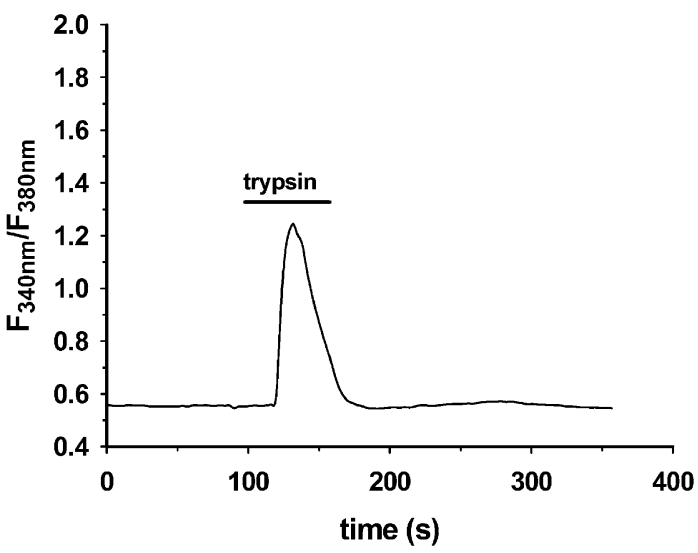

D

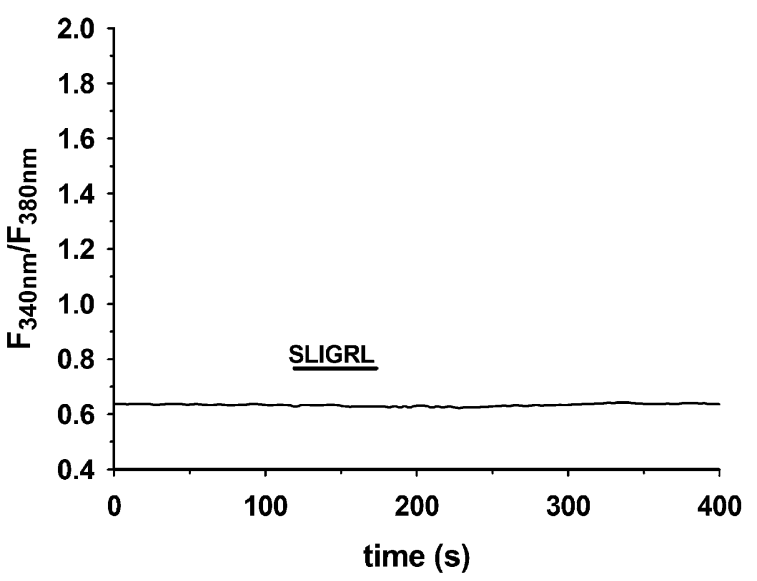

$\mathbf{F}$

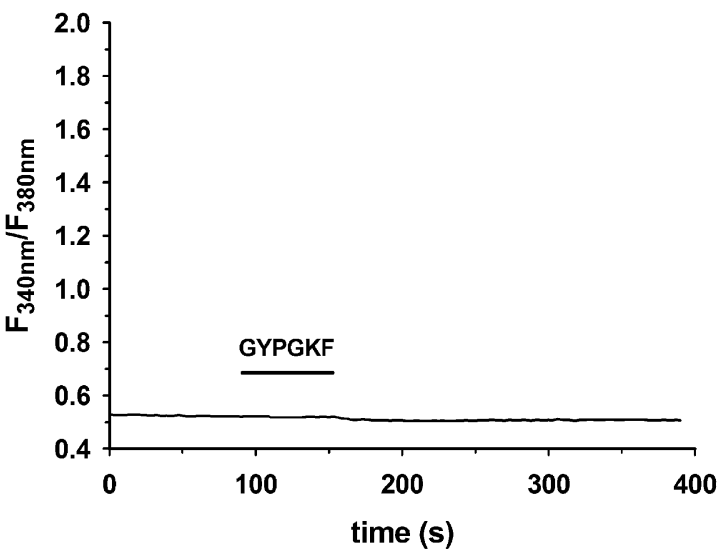

Fig. 4. $\mathrm{Ca}^{2+}$ responses induced by thrombin, trypsin and APs of PARs in OLN-93 cells. Cells were loaded with Fura-2/AM to measure the changes of the free cytosolic $\mathrm{Ca}^{2+}$ concentration indicated by the fluorescence ratio $\left(\mathrm{F}_{340 \mathrm{~nm}} / \mathrm{F}_{380 \mathrm{~nm}}\right)$. The time periods of application of $0.5 \mathrm{U} / \mathrm{ml}$ thrombin $(A)$, $100 \mathrm{nM}$ trypsin (B), $5 \mu \mathrm{M}$ TRag (C) and $500 \mu \mathrm{M}$ SLIGRL, TFRGAP and GYPGKF (D-F) are indicated by the respective bars. The traces are the mean responses from at least 10 single cells measured in a single experiment. The delay in the onset of the response is caused by the perfusion system.

The data in Fig. 1 show that OLN-93 cells mainly express PAR-1 (355 bp) and PAR-3 (581 bp), while PAR-2 (742 bp) and PAR-4 (559 bp) are not expressed. The identity of all PCR products was confirmed by sequencing analysis. The sequences of PAR-1 and PAR-3 PCR products are iden- tical to the sequences published in the Genbank (Genbank accession number: NM_012950 for rat PAR-1; AF310076 for rat PAR-3).

Previous analysis of the genes encoding PAR-1, PAR-2, PAR-3 and PAR-4 revealed that all these genes in 


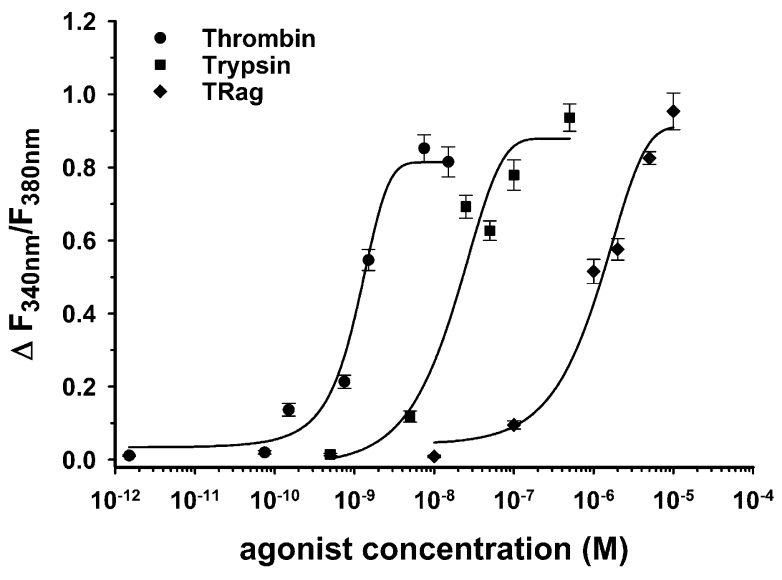

Fig. 5. Concentration-effect curves for $\left[\mathrm{Ca}^{2+}\right]_{\mathrm{i}}$ response induced by thrombin, TRag and trypsin in OLN-93. The concentration-effect curves display $\mathrm{Ca}^{2+}$ response amplitudes given by the respective maximum change in the fluorescence ratio $\left(\Delta F_{340} \mathrm{~nm} / F_{380 \mathrm{~nm}}\right)$ which is seen after a brief stimulation ( $60 \mathrm{~s}$ ) of OLN-93 cells with agonists at different concentrations. The data points represent the mean \pm S.E.M. of $50-130$ cells from three different experiments and two different preparations.

mouse and human have two exons, which are separated by one intron. The introns of PAR-1 and PAR-2 are about $10-15 \mathrm{~kb}$ long, while the size of the PAR-3 intron is about $4.5 \mathrm{~kb}$. However, the PAR-4 intron is much shorter. The human PAR-4 intron is $274 \mathrm{bp}$; the mouse PAR-4 intron is only $247 \mathrm{bp}$. The human PAR-4 intron is inserted at $D^{37}$ residue, which is identical to the position $E^{38}$ of the mouse intron (Kahn et al., 1998). Thus, the PAR-4 intron is more easily amplified from genomic DNA compared with the introns of the other PARs. In our experiments (Fig. 1), the sequence of the PCR product obtained with PAR-4 primers contains $854 \mathrm{bp}$. Within this sequence, $559 \mathrm{bp}$ are identical to the rat PAR-4 mRNA sequence (Genbank accession number: AF310216). In addition, there is an insert of 295 bp at residue $E^{37}$, which is in the identical position as the human and mouse intron in the respective gene. Thus, this insert sequence corresponds to the hitherto unknown sequence of rat PAR-4 intron which we determined for the first time here (the novel sequence is in Genbank, accession number AY517481). The intron sequence is shown here, as follows from 56 to 350 (exon sequence in bold, italic characters).

51 CCAAG GTGAG TGACTGTGTC TCTTGAAGGG GTGGATCAGA AATGGAGCTA

101 CTGCTGAGCA GGCTTACAGT CTTGGATCCC

TAAGCCCCCA TGCCTTTGGG

151 GCTGGGCTGT ATCCTTCCAT TCACCAGCCC AGGGTTCCTG AGTGCTGGAG

201 TGGGGAGGCT TAGGCACCCA CAATACCTAA

GACGCTCAAG GTCATTCTCC

251 CTTCATCTTG TATCCCTAAA GGCAGGGCAG GGCAGGGCAG GGCAGGGCAG

301 GGCAGGGCAG GGCAGGGAAG GGATTGACTG ATGTCCCCTC TCTCCCACAG

351 AAGCCTCTCT
Thus, the $854 \mathrm{bp}$ band was amplified from genomic DNA template, but not from cDNA. To make this clear, we additionally used mRNA from OLN-93 cells, which was not reverse transcribed, as template to carry out PCR. Again the PCR product of 854 bp was obtained (data not shown). These results indicate that the PAR-4 gene in the OLN-93 cells is silent.

To compare the expression of PARs in the OLN-93 cell line with that of cultured oligodendrocytes derived from rat brain, we checked the expression of PARs mRNA in primary oligodendrocytes at various times of differentiation (6 h, 1 day, 5 days, 7 days and 12 days). The expression of PARs was investigated in cell homogenates of oligodendrocytes. Oligodendrocyte precursor cells were separated from astrocytes, replated and incubated for the indicated times ( $6 \mathrm{~h}$ to 12 days). During the first week in culture precursor cells $(6 \mathrm{~h})$, characterized by their bipolar morphology, differentiate into oligodendrocytes with numerous cellular processes, expressing all major myelin specific proteins (Gorath et al., 2001). We found that oligodendrocytes at all those developmental stages analyzed express PAR-1, while the other three types of PAR could not be detected when we used the same PCR program (35 cycles) which we also used for OLN-93 cells (data in Fig. 2). However, when the number of PCR cycles in the program was increased to 40, PAR-2 and PAR-3 could also be detected (data not shown). These results suggest that primary cultured oligodendrocytes mainly express PAR-1, and to a lesser extent PAR-2 and PAR-3.

\section{Detection of PARs by immunofluorescence}

Indirect immunofluorescence was carried out to study protein expression of PARs in OLN-93 cells, using specific antibodies against PAR-1, PAR-2, PAR-3 and PAR-4 and a monoclonal CNPase antibody (Reiser et al., 1994). The latter is a marker for oligodendrocytes. Controls were made by omission of the primary antibodies or secondary antibodies. As negative controls PAR antibodies preincubated with specific antigen-blocking peptides were used. Fig. 3 demonstrates that PAR-1 and PAR-3 are present on the cell surface of OLN-93 cells and colocalize with CNPase. PAR-2 and PAR-4 are not expressed. No staining was observed in the control experiments.

\section{PAR-mediated $\mathrm{Ca}^{2+}$ mobilization in OLN-93 cells}

In order to study the functional implications of PARs for oligodendroglial cells, we stimulated OLN-93 cells with 0.5 $\mathrm{U} / \mathrm{ml}$ thrombin (approximately $7.5 \mathrm{nM}$ ), $100 \mathrm{nM}$ trypsin, $5 \mu \mathrm{M}$ thrombin receptor agonist (TRag; PAR-1 agonist; Feng et al., 1995), $500 \mu \mathrm{M}$ mouse and rat PAR-2 AP (peptide sequence: SLIGRL), $500 \mu \mathrm{M}$ human PAR-3 AP (peptide sequence: TFRGAP) and $500 \mu \mathrm{M}$ mouse PAR-4 AP (peptide sequence: GYPGKF) for $60 \mathrm{~s}$. Thrombin, trypsin and TRag induced a significant $\left[\mathrm{Ca}^{2+}\right]_{i}$ rise (Fig. 4AC). PAR-2 AP and PAR-4 AP, however, had no effect on $\left[\mathrm{Ca}^{2+}\right]_{\mathrm{i}}$ mobilization in OLN-93 cells (Fig. 4D, F). These results suggest that OLN-93 cells do not express detectable PAR-2 and PAR-4, which is consistent with the RT- 
PCR results. Human PAR-3 AP (TFRGAP), a peptide specific for human PAR-3, not for rat PAR-3, caused only very low amplitude calcium transients (Fig. 4E). However, until now the possible tethered ligand domain of rat PAR-3 is not yet clear. Other possibilities are that OLN-93 cells do not express functional PAR-3, or alternatively that PAR-3, which has been hypothesized to function as a chaperone for PAR-4 rather than a signaling receptor (NakanishiMatsui et al., 2000), may play a different role.

Fig. 5 represents the concentration-effect curves for thrombin, trypsin and TRag in OLN-93 cells. The points could be fitted by single sigmoidal curves, with $\mathrm{EC}_{50}$ values of $1.2 \mathrm{nM}$ for thrombin, $17 \mathrm{nM}$ for trypsin and $1.6 \mu \mathrm{M}$ for TRag.

\section{Desensitization of PAR-1 and ligand cross-reactivity in OLN-93 cells}

In order to study the desensitization of PARs in OLN-93 cells, we stimulated cells for a second time with proteases (test pulse of $60 \mathrm{~s}$ ), at $5 \mathrm{~min}$ interval after the first stimulus (pre-pulse of $60 \mathrm{~s}$ ). Fig. $6 \mathrm{~A}-\mathrm{F}$ demonstrates six alternative ways to stimulate cells consecutively with thrombin, trypsin and TRag. We analyze the mutual influence of stimulation by proteolysis or by peptide application.

The results of the experiments exemplified in Fig. 6 are summarized in Fig. 7. They indicate that a first proteolytic stimulation with either thrombin or non-proteolytic stimulation with TRag reduced the amplitude caused by thrombin as second agonist only by $41 \%$ and $49 \%$, respectively. However, a second addition of thrombin after a pre-pulse challenge with trypsin reduced the calcium transient to a much larger degree (by $80 \%$ ). When the second pulse (test pulse) contained trypsin, after firstly stimulating nonproteolytically with TRag, the calcium response was reduced weakly (by $28 \%$ ), while the application of trypsin by the test pulse after first proteolytic stimulation with thrombin or trypsin caused a largely reduced intracellular calcium response (by $73 \%$ and $80 \%$, respectively).

Cathepsin $\mathrm{G}$ is a neutrophil-derived protease that has been shown to inhibit the effects of thrombin on some cells expressing thrombin receptors, while acting as an agonist on some other cells, and hence has cell type specific effects (Molino et al., 1995). To further clarify desensitization and cross-reactivity of PAR-1 in OLN-93 cells, we used cathepsin $\mathrm{G}(0.01 \mathrm{U} / \mathrm{ml})$ as first agonist (pre-prepulse) to stimulate cells, and then after a second agonist (pre-pulse) of trypsin $(100 \mathrm{nM})$, thrombin $(0.5 \mathrm{U} / \mathrm{ml})$ was employed as third agonist (test pulse; Fig. 8A). In addition, we also studied desensitization of PARs in other ways. The summary of the results is presented in Fig. 8B. Our experiments show that cathepsin $\mathrm{G}$ caused only very limited or negligible intracellular calcium mobilization, but it significantly reduced the amplitude induced by secondly adding thrombin, trypsin or TRag, by $41 \%, 20 \%$ and $33 \%$, respectively (Fig. 8B). This indicates that cathepsin G cannot activate PARs in OLN-93 cells by itself, but it cleaves PARs at some site which affects the responsiveness that can be elicited by the agonists thrombin, trypsin and TRag.
To evaluate the differences in desensitization caused by either three or two successive pulses of different agonists, the most important results are presented as a numerical comparative overview in Table 1. Data in Table 1 show that cathepsin $G$ reduced the calcium responses induced by test pulses of thrombin, trypsin and TRag after respective pre-pulses to a different degree. The pre-pulse of trypsin reduced the calcium response induced by a test pulse of thrombin by $80 \%$. The reduction was similar after pre-pre-pulse of cathepsin $G$ and pre-pulse of trypsin $(76 \%)$. Thrombin as pre-pulse abolished the trypsininduced calcium response by $73 \%$, which is similar to the effects of cathepsin $G$ and thrombin as two consecutive pre-pulses abolishing the trypsin-induced calcium responses (by 68\%). In addition, the non-proteolytic stimulation with TRag reduced thrombin-induced calcium responses only by $49 \%$. Similarly, consecutive challenges with cathepsin $\mathrm{G}$ and TRag also suppressed the thrombininduced calcium response only by $44 \%$.

However, the amplitude induced by trypsin as third stimulus (test pulse) after consecutive cathepsin $G$ and TRag stimuli was reduced by $62 \%$. This was significantly more than the degree of desensitization of the response to trypsin by a preceding application of TRag (by $28 \%$ ). Thus, cathepsin $\mathrm{G}$ has no effect on the calcium responses induced by the addition of thrombin as a third pulse, given after a pre-pulse of TRag or trypsin. However, cathepsin G had a remarkable reducing effect on a test pulse of trypsin after TRag stimulation. This potentiation was not seen after thrombin pre-pulse stimulation.

\section{Elucidation of the signaling mechanism of PAR-1- induced $\mathrm{Ca}^{2+}$ rise}

To study the calcium source for the transient intracellular calcium rise, we compared the amplitude induced by thrombin, trypsin and TRag in the presence of extracellular $\mathrm{Ca}^{2+}\left(1.8 \mathrm{mM} \mathrm{CaCl}_{2}\right)$ and in its absence (no $\mathrm{CaCl}_{2}$ added). Omission of extracellular $\mathrm{Ca}^{2+}$ reduced the amplitude induced by thrombin, trypsin and TRag by $31 \%, 25 \%$ and $15 \%$, respectively (Fig. 9). These results indicate that elevation of intracellular calcium induced by PARs mainly results from $\mathrm{Ca}^{2+}$ release from intracellular stores, and only to a small extent $(15 \%-30 \%)$ from $\mathrm{Ca}^{2+}$ influx.

One major aim of this study is to investigate whether the intracellular calcium response in OLN-93 cells is generated through PAR-1 activation or through both PAR-1 and PAR-3 activation. In this experiment, we preincubated cells with the thrombin receptor (PAR-1) antagonist (YFLLRNP, $200 \mu \mathrm{M}$ ) during the 30 min Fura-2/AM loading period, and then studied the $\left[\mathrm{Ca}^{2+}\right]_{\mathrm{i}}$ responses induced by thrombin, trypsin and TRag. Fig. 10 shows that YFLLRNP reduced the $\left[\mathrm{Ca}^{2+}\right]_{\mathrm{i}}$ responses induced by thrombin, trypsin and TRag by $94 \%, 88 \%$ and $96 \%$, respectively. These results suggest that the $\left[\mathrm{Ca}^{2+}\right]_{i}$ responses induced by thrombin, trypsin and TRag are almost exclusively due to activation of PAR-1, but not of PAR-3. Whether rat PAR-3 can be activated by thrombin needs further investigations.

It is well known that PTX can inactivate the $G_{i} / G_{o}$ family but does not affect $G_{s}, G_{q}$ and $G_{12 / 13}$. To study whether in 
A

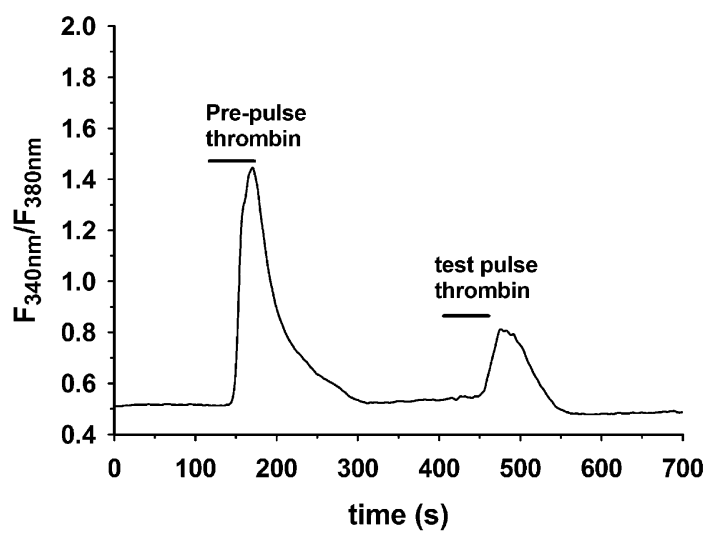

C

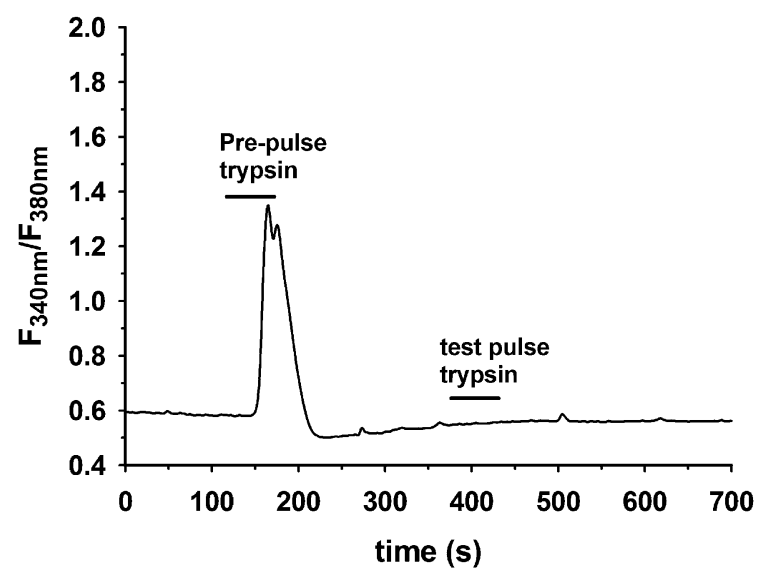

E

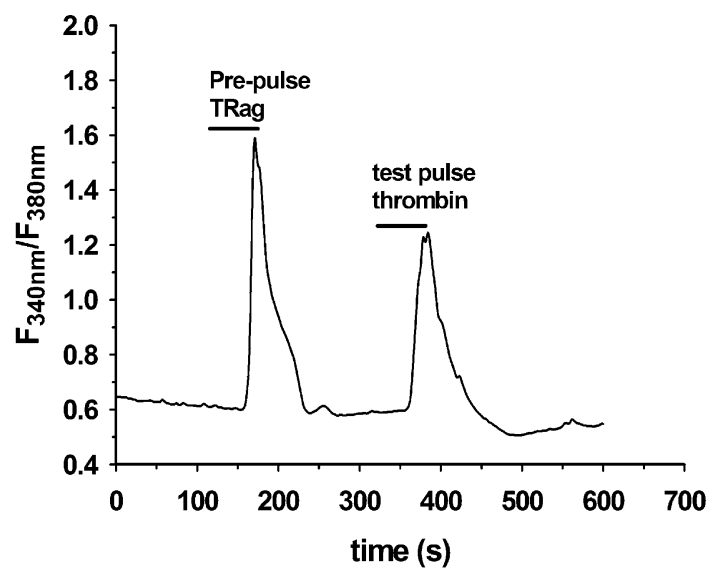

B

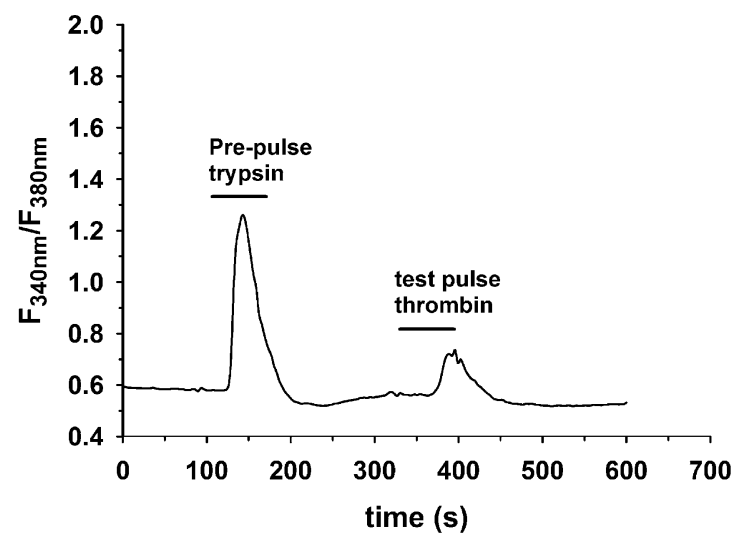

D

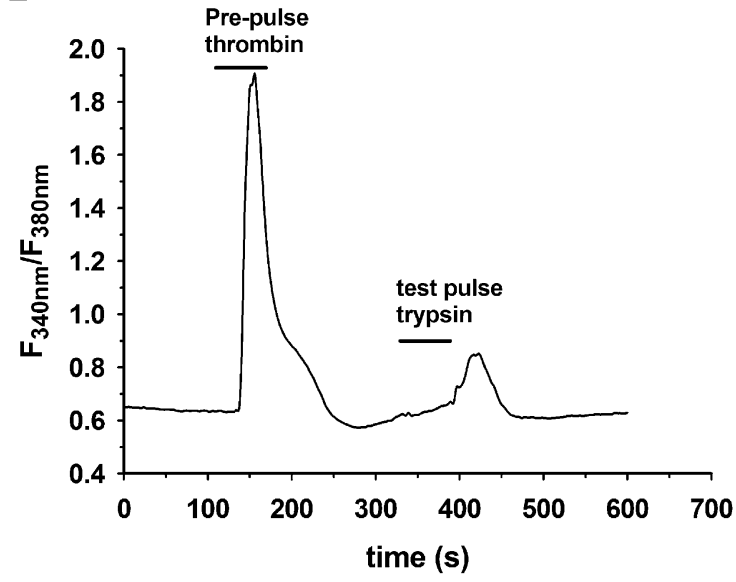

F

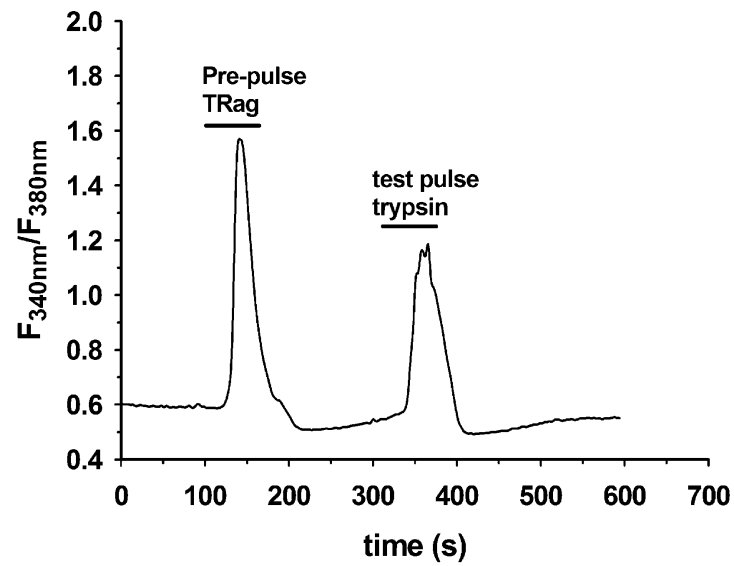

Fig. 6. $\left[\mathrm{Ca}^{2+}\right]_{\mathrm{i}}$ responses in OLN-93 cells induced by two successive stimulations with different agonists of PARs. The traces give the Ca ${ }^{2+}$ responses indicated by the fluorescence ratio $\left(\mathrm{F}_{340 \mathrm{~nm}} / \mathrm{F}_{380 \mathrm{~nm}}\right)$. The traces in $\mathrm{A}, \mathrm{B}$ and $\mathrm{E}$ show $\left[\mathrm{Ca}^{2+}\right]_{\mathrm{i}}$ responses to $0.5 \mathrm{U} / \mathrm{ml}$ thrombin (test pulse), obtained at $5 \mathrm{~min}$ after a first addition (pre-pulse) of $0.5 \mathrm{U} / \mathrm{ml}$ thrombin, $100 \mathrm{nM}$ trypsin or $5 \mu \mathrm{M}$ TRag, respectively. The traces in $\mathrm{C}, \mathrm{D}$ and $\mathrm{F}$ show [Ca $\left.{ }^{2+}\right]_{\mathrm{i}}$ responses to $100 \mathrm{nM}$ trypsin (test pulse), obtained at $5 \mathrm{~min}$ after the first application (pre-pulse) of $100 \mathrm{nM}$ trypsin, $0.5 \mathrm{U} / \mathrm{ml}$ thrombin or $5 \mu \mathrm{M}$ TRag, respectively. The traces are the mean responses from at least 10 single cells measured in a single experiment. The delay in the onset of the response is caused by the perfusion system.

oligodendrocytes the signaling cascade from PAR-1 is mediated through the $G_{i} / G_{0}$ family or other $G$ proteins, cells were preincubated with PTX $(200 \mathrm{ng} / \mathrm{ml})$ for $24 \mathrm{~h}$ before the stimulation. As shown in Fig. 10, the increase of intracellular calcium evoked by thrombin and trypsin was attenuated by only $33 \%$ and $16 \%$, respectively. But PTX 


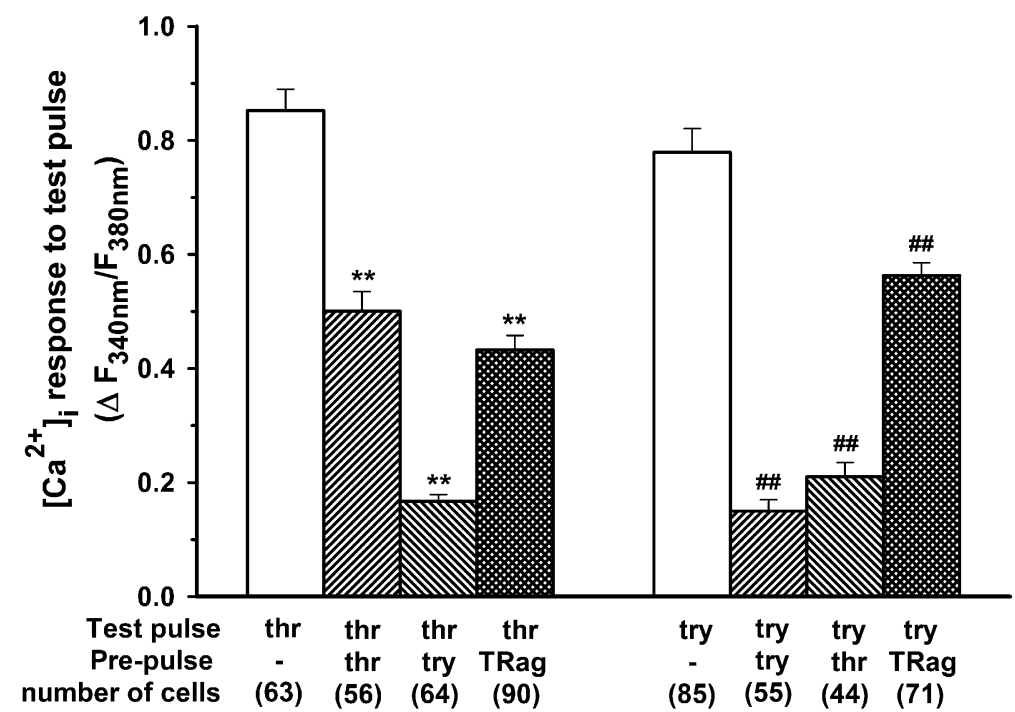

Fig. 7. $\left[\mathrm{Ca}^{2+}\right]_{\mathrm{i}}$ responses in OLN-93 cells induced by two successive stimulations with different agonists of PARs. OLN-93 cells were treated with pre-pulse and test pulse successively, as shown in Fig. 6 . The bars represent the maximum change in the fluorescence ratio $\left(\Delta F_{340} \mathrm{~nm} / F_{380 \mathrm{~nm}}\right)$ seen after the test pulse $(60 \mathrm{~s})$. The composite results present the mean \pm S.E.M. of $n$ single cells (number of cells) measured from at least three different experiments and two different cell preparations. The statistical significance level for difference from control is given as: ${ }^{* *} P<0.01$ for the thrombin control response; ${ }^{\#} P<0.01$ for the trypsin control response, by Dunnett's multiple comparison test.

had virtually no effect on the $\left[\mathrm{Ca}^{2+}\right]_{\mathrm{i}}$ response induced by TRag. These results indicate that the calcium signaling cascade from PAR-1 was mediated mainly through PTXinsensitive $G$ proteins.

Previous data already showed that PARs activate phospholipase C (PLC), which converts membrane bound phosphatidyl inositol (4,5)-bisphosphate into inositol trisphosphate $\left(\operatorname{lns}_{3}\right)$ and diacylglycerol. InsP $\mathrm{P}_{3}$ diffuses into the cytoplasm and triggers release of $\mathrm{Ca}^{2+}$ from the endoplasmic reticulum by binding to $\mathrm{InsP}_{3}$ receptors (Wang et al., 2002b). To determine whether PLC and Ins $\mathrm{P}_{3}$ are upstream factors of the $\mathrm{Ca}^{2+}$ release from the stores, cells were superfused with $5 \mu \mathrm{M}$ U73122 (PLC antagonist), U73343 (an inactive analog of U73122), and $500 \mu \mathrm{M}$ 2-APB (InsP 3 receptor antagonist) for $5 \mathrm{~min}$ before the stimulation. The thrombin-induced $\left[\mathrm{Ca}^{2+}\right]_{\mathrm{i}}$ responses and trypsin-induced $\left[\mathrm{Ca}^{2+}\right]_{\mathrm{i}}$ responses were both blocked by $U 73122$ by $60 \%$ and $46 \%$, respectively. Surprisingly, TRag-induced $\left[\mathrm{Ca}^{2+}\right]_{i}$ response was blocked very weakly (only by $14 \%$ ), as shown in Fig. 10. The inactive analog U73343 had no effect on $\left[\mathrm{Ca}^{2+}\right]_{i}$ mobilization in OLN-93 cells. These results implicate that thrombin, trypsin and TRag induced the $\left[\mathrm{Ca}^{2+}\right]_{\mathrm{i}}$ responses at least in part via the PLC activation. 2-APB, a non-competitive antagonist of the intracellular Ins $\mathrm{P}_{3}$ receptor, almost completely inhibited the $\left[\mathrm{Ca}^{2+}\right]_{\mathrm{i}}$ responses induced by thrombin, trypsin and TRag. These results are consistent with the data determining the source of calcium (Fig. 9).

\section{DISCUSSION}

PARs have already been demonstrated on neurons, astrocytes and microglia cells. In peripheral and central neurons, PARs possibly are involved not only in neurogenic inflammation and neurodegenerative processes, but also in nocicep- tion (Vergnolle et al., 2001). Also, PAR-1 determines the effects of thrombin on cell morphology, calcium mobilization, and caspase-mediated apoptosis (Smirnova et al., 2001). In microglia cells, PAR-1 directly contributes to thrombin-induced microglial proliferation and participates in thrombinmediated microglia activation, where it induces a rapid increase in $\left[\mathrm{Ca}^{2+}\right]_{\mathrm{i}}$ (Moller et al., 2000; Suo et al., 2002). In astrocytes, PARs can modulate cell proliferation via activation of the extracellular signal-regulated kinase (ERK) pathway (Wang et al., 2002b; Wang and Reiser, 2003).

In contrast to astrocytes, which functionally express all four types of PARs (Wang et al., 2002a), OLN-93 oligodendroglial cells functionally express PAR-1, whereas PAR-3 seems to be expressed without apparent functional activity. These results were further supported by indirect immunofluorescence data, which demonstrate the distinct presence of PAR-1 and PAR-3 protein on the cell surface of OLN-93 cells in colocalization with CNPase. CNPase is an oligodendroglial marker which in the CNS is predominantly found in the CNS myelin in the oligodendroglia membrane, in paranodal segments and in periaxonal regions (Muraro et al., 2002). Furthermore, primary oligodendrocytes only express PAR-1.

In the present study, results from cytosolic $\mathrm{Ca}^{2+}$ measurements proved that thrombin, trypsin and TRag mobilized intracellular free $\mathrm{Ca}^{2+}$, but APs of PAR-2 and PAR-4 could not cause intracellular free $\mathrm{Ca}^{2+}$ mobilization. Human PAR-3 AP (TFRGAP) induced a very small calcium response, with an amplitude $\left(\Delta \mathrm{F}_{340 \mathrm{~nm}} / \mathrm{F}_{380 \mathrm{~nm}}\right)$ of only about 0.02 . In contrast, our previous data had shown that TFRGAP was considerably more effective in inducing $\mathrm{Ca}^{2+}$ signaling in astrocytes (Wang et al., 2002a).

Results from the desensitization assay (Fig. 7) and experiments with the PAR-1 antagonist peptide YFLLRNP 
A

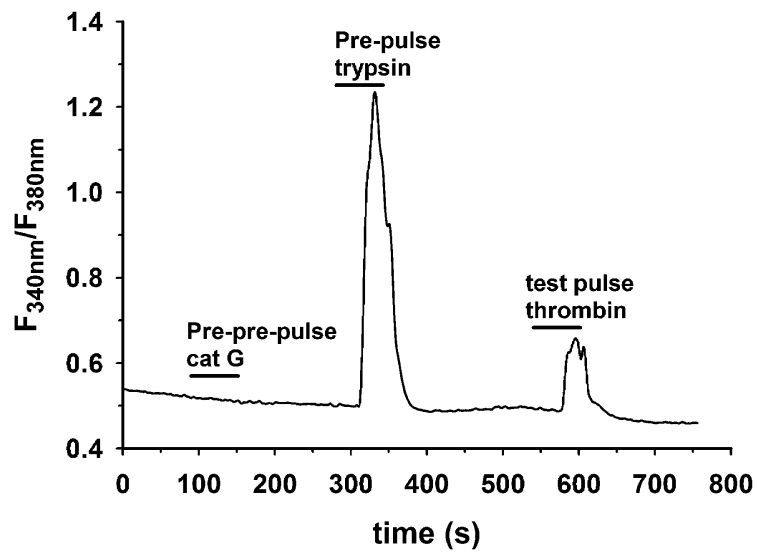

B

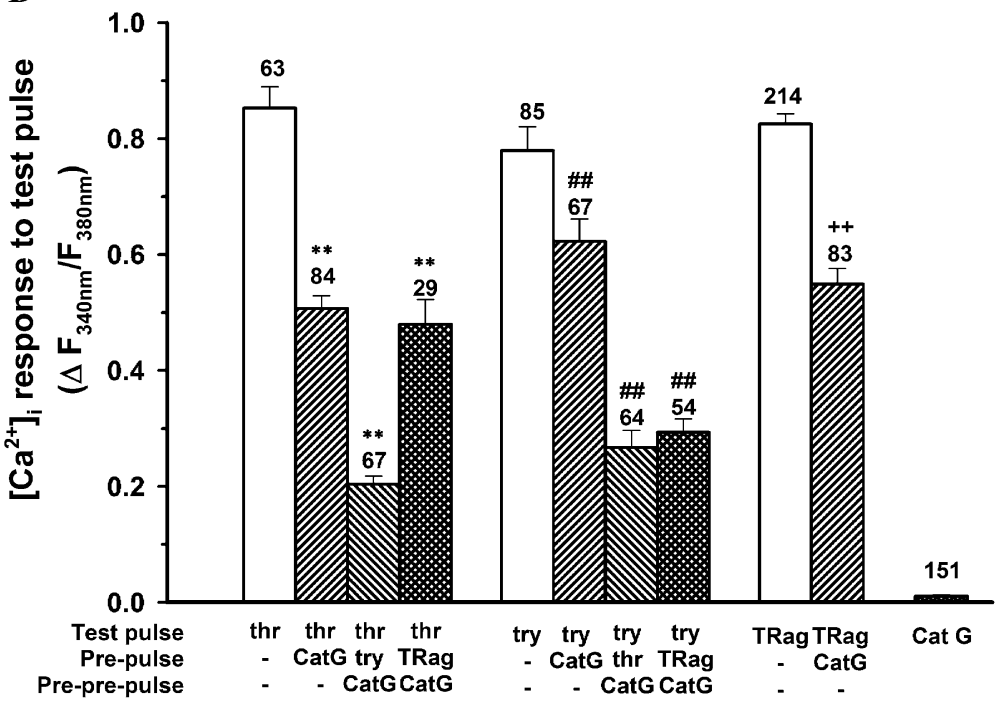

Fig. 8. $\left[\mathrm{Ca}^{2+}\right]_{i}$ responses in OLN-93 cells induced by three successive stimulations with cathepsin $\mathrm{G}$, thrombin, trypsin or TRag. The example trace in $A$ shows the $\mathrm{Ca}^{2+}$ response indicated by the fluorescence ratio $\left(F_{340 \mathrm{~nm}} / F_{380 \mathrm{~nm}}\right)$, the bars in chart $B$ represent the maximum changes in the fluorescence ratio $\left(\Delta \mathrm{F}_{340 \mathrm{~nm}} / \mathrm{F}_{380 \mathrm{~nm}}\right)$ seen with the test pulse. (A) OLN-93 cells were first exposed to $0.01 \mathrm{U} / \mathrm{ml}$ cathepsin $\mathrm{G}$ (cat G; pre-pre-pulse), followed by second addition of $100 \mathrm{nM}$ trypsin (pre-pulse), then cells were stimulated by third agonist $0.5 \mathrm{U} / \mathrm{ml}$ thrombin (test pulse). (B) OLN-93 cells were first exposed to $0.01 \mathrm{U} / \mathrm{ml}$ cathepsin G (Cat G; pre-pre-pulse), followed by second addition (pre-pulse) of $100 \mathrm{nM}$ trypsin or $5 \mu \mathrm{M}$ TRag, then cells were stimulated by third agonist (test pulse) $0.5 \mathrm{U} / \mathrm{ml}$ thrombin, or cells were exposed to $0.5 \mathrm{U} / \mathrm{ml}$ thrombin or $5 \mu \mathrm{M}$ TRag (pre-pulse) 3-5 min after first addition of $0.01 \mathrm{U} / \mathrm{ml}$ cathepsin G (pre-pre-pulse), 3-5 min thereafter $100 \mathrm{nM}$ trypsin (test pulse) were added. The data shown are the mean \pm S.E.M. of $n$ single cells (numbers of cells given above the respective column) measured from at least three different experiments and two different cell preparations. The statistical significance level for difference from control is given as: ${ }^{* *} P<0.01$ for the thrombin control response; ${ }^{\# \#} P<0.01$ for the trypsin control response; ${ }^{++} P<0.01$ for the TRag control response, by Dunnett's multiple comparison test.

(Fig. 10) prove that thrombin activates PAR-1, but not PAR-3 in OLN-93 cells. Trypsin, the agonist of PAR-2, can similarly activate PAR-1. It still remains unknown whether thrombin can activate rat PAR-3 or not. Rat PAR-3 has a glutamyl residue at position $\mathrm{P} 1$ of the cleavage site (Owen, 2003), which makes hydrolysis by thrombin very unlikely at all. This suggests that rat PAR- 3 cannot be activated by thrombin. In addition, the concept was put forward that PAR-3 is a non-signaling cofactor, aiding the activation of PAR-4 by thrombin in mouse platelets (Nakanishi-Matsui et al., 2000).

A major aim of the present study was to investigate desensitization of PARs in OLN-93 cells by thrombin, trypsin and cathepsin G. It is established that trypsin cleaves peptides C-terminally to Arg or Lys residues, and that it prefers Gly or Pro residues in P2 position (Zhao et al., 2003). Sequence analysis of rat PAR-1 revealed two potential cleavage sites for trypsin: $\mathrm{Pro}^{44}-\mathrm{Arg}^{45}$ and Gly ${ }^{76}$ $\operatorname{Arg}^{77}$. The data in Fig. 7, Fig. 8 and Table 1 show that the proteases thrombin and trypsin both induce a similar degree of calcium mobilization in OLN-93 cells. However, from the thrombin-induced $\mathrm{Ca}^{2+}$ responses, it seems that a pre-pulse of trypsin induces a larger desensitization than a pre-pulse of thrombin does. This difference was similarly seen in our previous results obtained with rat astrocytes (Ubl et al., 1998). Surprisingly, trypsin stimulation after the pre-pulse addition of thrombin shows a comparably large desensitization as trypsin stimulation after the pre-pulse challenge with trypsin. The reason might be that trypsin can cleave rat PAR-1 at the two positions indicated above. 
Table 1. Desensitization of $\left[\mathrm{Ca}^{2+}\right]_{\mathrm{i}}$ responses to thrombin, trypsin, TRag and cathepsin $\mathrm{G}$ in OLN-93 cells ${ }^{\mathrm{a}}$

\begin{tabular}{lllll}
\hline $\begin{array}{l}\text { First agonist } \\
\text { (pre-pre-pulse) }\end{array}$ & $\begin{array}{l}\text { Second agonist } \\
\text { (pre-pulse) }\end{array}$ & $\begin{array}{l}\text { Third agonist } \\
\text { (test pulse) }\end{array}$ & Amplitude $\left(\Delta \mathrm{F}_{340 \mathrm{~nm}} / \mathrm{F}_{380 \mathrm{~nm}}\right)$ & $\begin{array}{l}\text { Desensitization } \\
(\%)\end{array}$ \\
\hline$-^{\mathrm{b}}$ & - & Thrombin & $0.8523 \pm 0.0372(63)$ & - \\
- & trypsin & thrombin & $0.1669 \pm 0.0114(64)^{\star *}$ & 80 \\
Cathepsin G & trypsin & thrombin & $0.2033 \pm 0.0145(67)^{\star *}$ & 76 \\
- & TRag & thrombin & $0.4324 \pm 0.0252(90)^{\star *}$ & 49 \\
Cathepsin G & TRag & thrombin & $0.4793 \pm 0.0431(29)^{\star *}$ & - \\
- & - & trypsin & $0.7791 \pm 0.0415(85)$ & 74 \\
- & thrombin & trypsin & $0.2102 \pm 0.0247(44)^{\# \#}$ & \\
Cathepsin G & thrombin & trypsin & $0.2667 \pm 0.0299(64)^{\# \#}$ & 68 \\
- & TRag & trypsin & $0.5630 \pm 0.0230(71)^{\# \#}$ & 28 \\
Cathepsin G & TRag & trypsin & $0.2933 \pm 0.0230(54)^{\# \#}$ & 62
\end{tabular}

${ }^{a}$ The responses induced by thrombin $(0.5 \mathrm{U} / \mathrm{ml})$ or trypsin $(100 \mathrm{nM})$ only were regarded as control. For desensitization experiments OLN-93 cells were stimulated successively by two or three different agonists. As shown in Fig. 6, OLN-93 cells were exposed to two successive pulses (pre-pulse and test pulse), or as shown in Fig. 8B, cells were treated by three successive stimuli. Cells were firstly exposed to human cathepsin $\mathrm{G}(0.01 \mathrm{U} / \mathrm{ml}$; pre-pre-pulse), with a following stimulation of thrombin $(0.5 \mathrm{U} / \mathrm{ml})$, trypsin $(100 \mathrm{nM})$ or TRag $(5 \mu \mathrm{M}$; pre-pulse), then cells were stimulated with the third agonist (thrombin or trypsin) as test pulse. Each stimulation lasted for $1 \mathrm{~min}$. The number of cells tested is indicated in parentheses. The data shown are the mean \pm S.E.M. measured from at least three different experiments and two different cell preparations. The statistical significance level for difference from control is given as: ${ }^{* *} P<0.01$ for the thrombin control response $(0.8523 \pm 0.0372) ;{ }^{\#} P<0.01$ for the trypsin control response ( $0.7791 \pm 0.0415)$, by Dunnett's multiple comparison test.

${ }^{b}-$, indicates application of buffer without agonist.

If trypsin cleaves at position $\mathrm{Pro}^{44}-\mathrm{Arg}^{45}$, it unmasks the $\mathrm{N}$-terminal tethered ligand domain, and thus activates PAR-1 and causes calcium mobilization. However, cleavage at $\mathrm{Gly}^{76}-\mathrm{Arg}^{77}$ will result in inactive PAR-1, which cannot cause the calcium mobilization.

Cathepsin $G$ has been shown to have two apparently contradictory effects. In some cells that express thrombin receptors, including platelets (LaRosa et al., 1994; Molino et al., 1992) and porcine aortic endothelial cells (Totani et al., 1994), cathepsin $\mathrm{G}$ acts as an agonist causing $\left[\mathrm{Ca}^{2+}\right]_{i}$ mobilization. In contrast, in human umbilical vein endothelial cells (Weksler et al., 1989) and fibroblasts (Selak, 1994), cathepsin G has no agonist effect. Binding studies showed that cathepsin $G$ cleaves the human thrombin

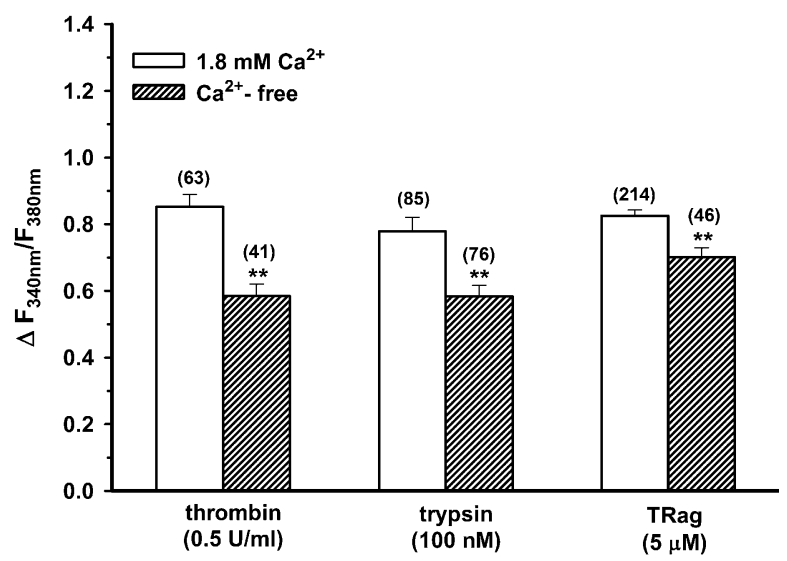

Fig. 9. $\left[\mathrm{Ca}^{2+}\right]_{\mathrm{i}}$ responses induced by thrombin, trypsin and TRag in the presence or absence of extracellular calcium. The bars represent the maximum changes in the fluorescence ratio $\left(\Delta F_{340} \mathrm{~nm} / \mathrm{F}_{380 \mathrm{~nm}}\right)$ seen after respective agonist stimulation. The values are the mean \pm S.E.M. of $n$ single cells measured from at least three different experiments and two different cell preparations. ${ }^{* *} P<0.01$ for the respective control response, by $t$-test. receptor at three sites: $\mathrm{Arg}^{41}-\mathrm{Ser}^{42}, \mathrm{Phe}^{43}-\mathrm{Leu}^{44}$, and Phe ${ }^{55}-\operatorname{Trp}^{56}$ (Molino et al., 1995). Previously it has already been shown that cathepsin $\mathrm{G}$ might cleave C-terminally to Lys, Phe, Arg and Leu, and that cathepsin G prefers a Pro residue in P2 position (Polanowska et al., 1998). Several possible potential cathepsin $\mathrm{G}$ cleavage sites are present in the rat PAR-1 sequence: $\mathrm{Arg}^{45}-\mathrm{Ser}^{46}$, $\mathrm{Leu}^{62}-\mathrm{Gly}^{63}$ and $\mathrm{Leu}^{74}-\mathrm{Glu}^{75}$. Cleavage at Leu ${ }^{62}-\mathrm{Gly}^{63}$ and Leu ${ }^{74}-\mathrm{Glu}^{75}$ would account for the inhibition of receptor activation by thrombin, while cleavage at $\mathrm{Arg}^{45}-\mathrm{Ser}^{46}$ would result in receptor activation. It has already been demonstrated that cathepsin $\mathrm{G}$ can activate different types of PARs (Sambrano et al., 2000).

Our results show that cathepsin $G$ has no effect of its own on $\mathrm{Ca}^{2+}$ release. Moreover, cathepsin $\mathrm{G}$ reduced the calcium responses induced by a second stimulation (test pulse) with thrombin, trypsin or TRag to a different degree (Fig. 8). Thus, we conclude that cathepsin $G$ probably partially cleaved PAR-1 of OLN-93 cells at sites, which might result in inhibition of the effects of thrombin, trypsin and Trag. However, cathepsin G did not affect the reduction of the calcium responses induced by the addition of thrombin and trypsin as third agonist (test pulse), given after a pre-pulse of the other proteases (Fig. 8 and Table $1)$. The only striking effect was seen when trypsin was given as the test pulse after cathepsin G (pre-pre-pulse) and TRag (pre-pulse) challenges. The desensitization of $62 \%$ achieved in that case was much more than that induced by a TRag pre-pulse before a trypsin test-pulse (28\%). This potentiation seems to be due to a still not yet clearly identified cleavage site of cathepsin G in rat PAR-1.

It has been well established in our previous analysis that in astrocytes the signaling cascade from PAR-1 to the ERK pathway is mediated through PTX-sensitive as well as PTX-insensitive G proteins (Wang et al., 2002b). In the present study, we found that in OLN-93 oligodendrocytes 


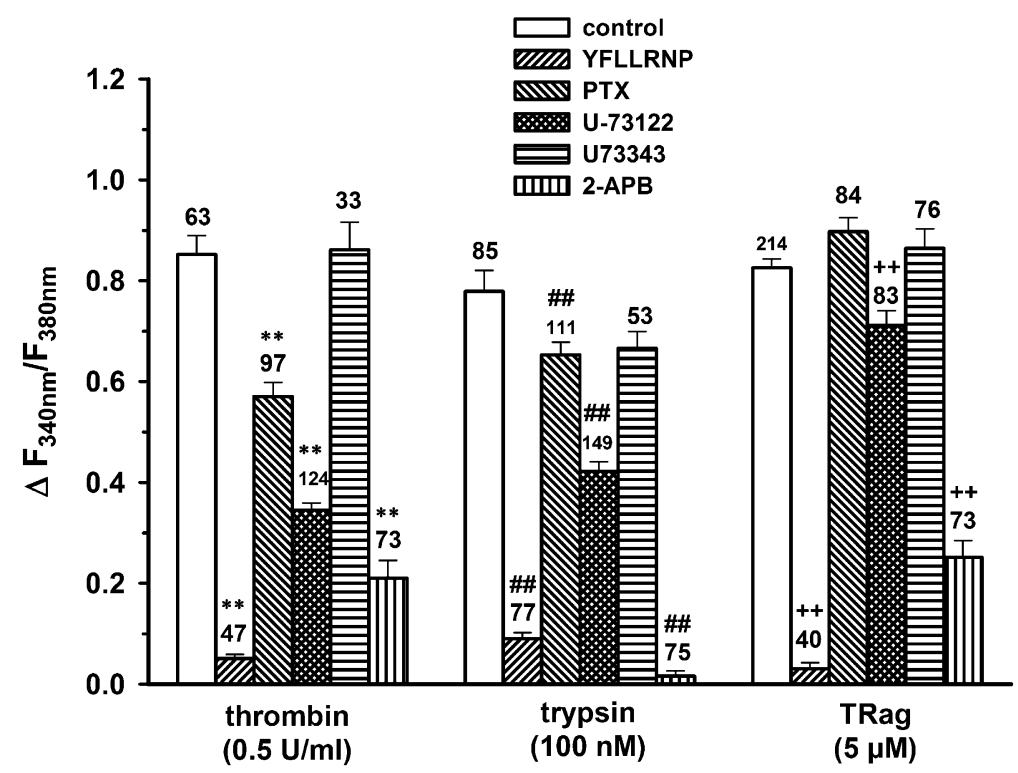

Fig. 10. Effects of thrombin receptor PAR-1 antagonist (YFLLRNP), PTX, U73122 and 2-APB on the $\left[\mathrm{Ca}^{2+}\right]_{\mathrm{i}}$ responses induced by thrombin, trypsin and TRag. Serum-free OLN-93 cells were preincubated with $200 \mu \mathrm{M}$ YFLLRNP during the 30 min Fura-2 loading period, and continued to be treated for $5 \mathrm{~min}$ before $1 \mathrm{~min}$ stimulation by $0.5 \mathrm{U} / \mathrm{ml}$ thrombin, $100 \mathrm{nM}$ trypsin and $5 \mu \mathrm{M}$ TRag together with YFLLRNP; or preincubated with $200 \mathrm{ng} / \mathrm{ml}$ PTX for $24 \mathrm{~h}$ prior to $5 \mathrm{~min}$ stimulation with agonists; or pre-superfused with $5 \mu \mathrm{M}$ U73122, U73343 and $500 \mu \mathrm{M}$ 2-APB for 5 min prior to the experiments, cells were stimulated by the agonists indicated together with U73122, U73343 and 2-APB for 1 min. The maximum change in fluorescence ratio $\left(\Delta \mathrm{F}_{340 \mathrm{~nm}} / \mathrm{F}_{380 \mathrm{~nm}}\right)$ was measured in single cells. The data shown are the mean \pm S.E.M. of $n$ single cells measured from at least three different experiments and two different cell preparations. The statistical significance level for difference from control is given as: ${ }^{* *} P<0.01$ for the thrombin control response; ${ }^{\#} P<0.01$ for the trypsin control response; ${ }^{++} P<0.01$ for the TRag control response, by Dunnett's multiple comparison test.

the calcium signaling cascade from PAR-1 was mediated mainly through PTX-insensitive G proteins.

Our previous data showed that prolonged (30 min) incubation with $10 \mu \mathrm{M}$ U73122 but not with $10 \mu \mathrm{M}$ of the inactive analog U73343 completely abolished the trypsinevoked $\mathrm{Ca}^{2+}$ response in the epithelial cell lines (Ubl et al.,

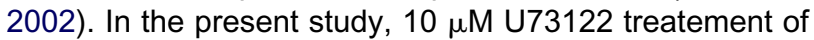
OLN-93 cells reduced $\mathrm{Ca}^{2+}$ responses induced by thrombin, trypsin and TRag by $60-70 \%$ (data not shown). However, such high concentration of U73122 will affect basal $\mathrm{Ca}^{2+}$ mobilization by itself. To avoid this problem, the lower concentration (5 $\mu \mathrm{M})$ of U73122 was used in our study. Fig. 10 shows that the PLC antagonist U73122 significantly reduced the calcium responses induced by thrombin, trypsin and TRag. However, the reduction by U73122 was very limited. In addition, the calcium response caused by TRag was much less reduced than those of thrombin and trypsin. The narrow inhibitory range of U73122 might be due to the fact that U73122 is not a selective inhibitor of PLC (see for example Walker et al., 1998). Otherwise PLC activation might depend on the mode of PAR activation. 2-APB almost completely abolished the calcium responses induced by thrombin, trypsin and TRag. These results suggest that liberation of $\operatorname{Ins} P_{3}$ was the event upstream of the $\mathrm{Ca}^{2+}$ release from the stores.

To summarize, the present data demonstrate that shortterm stimulation of OLN-93 oligodendroglial cells with thrombin, trypsin and PAR-1 AP (TRag) dose-dependently induced a transient rise of $\left[\mathrm{Ca}^{2+}\right]_{i}$, which mainly resulted from $\mathrm{Ca}^{2+}$ release from intracellular stores. Desensitization experi- ments indicated the influence of cathepsin G on PAR-1 activation, and also elucidated the mechanism of rat PAR-1 desensitization. Experiments investigating the effects of PTX, U73122 and 2-APB, showed that in OLN-93 cells the calcium signaling cascade from PAR-1 was mediated through PTX-insensitive $\mathrm{G}$ proteins, the activation of $P L C$ and the liberation of $\operatorname{Ins} P_{3}$. This is the first study to show that OLN-93 oligodendrocytes functionally express PAR-1, and that PAR-1 is coupled to the mobilization of intracellular calcium. It will be an interesting task for the future to clarify the functions of oligodendroglial PAR-1 in vivo.

Acknowledgements-The authors thank Dr. Theo Hanck for the help with DNA sequencing; Dr. Gregor Zündorf, Dr. Rolf Stricker and Mohan Tulapurkar for the help with confocal laser scanning microscopy. This work was supported by grants from the Deutsche Forschungsgemeinschaft (Graduiertenkolleg für 'Biologische Grundlagen von Erkrankungen des Nervensystems'). Land Sachsen-Anhalt (grant 2923A/0028H), Bundesministerium für Bildung und Forschung (01-ZZ 9505) and Fonds der chemischen Industrie.

\section{REFERENCES}

Asokananthan N, Graham PT, Fink J, Knight DA, Bakker AJ, McWilliam AS, Thompson PJ, Stewart GA (2002) Activation of proteaseactivated receptor (PAR)-1, PAR-2, and PAR-4 stimulates IL-6, $\mathrm{IL}-8$, and prostaglandin E2 release from human respiratory epithelial cells. J Immunol 168:3577-3585.

Berger P, Tunon-De-Lara JM, Savineau JP, Marthan R (2001) Selected contribution: tryptase-induced PAR-2-mediated $\mathrm{Ca}^{2+}$ signaling in human airway smooth muscle cells. J Appl Physiol 91:995-1003. 
Boven LA, Vergnolle N, Henry SD, Silva C, Imai Y, Holden J, Warren K, Hollenberg MD, Power C (2003) Up-regulation of proteinaseactivated receptor 1 expression in astrocytes during HIV encephalitis. J Immunol 170:2638-2646.

Carreno-Muller E, Herrera AJ, de Pablos RM, Tomas-Camardiel M, Venero JL, Cano J, Machado A (2003) Thrombin induces in vivo degeneration of nigral dopaminergic neurones along with the activation of microglia. J Neurochem 84:1201-1214.

Cirino G, Cicala C, Bucci MR, Sorrentino L, Maraganore JM, Stone SR (1996) Thrombin functions as an inflammatory mediator through activation of its receptor. J Exp Med 183:821-827.

Cole K, Kohn E (1994) Calcium-mediated signal transduction: biology, biochemistry, and therapy. Cancer Metastasis Rev 13:31-44.

Dihanich M, Kaser M, Reinhard E, Cunningham D, Monard D (1991) Prothrombin mRNA is expressed by cells of the nervous system. Neuron 6:575-581.

Du Y, Dreyfus CF (2002) Oligodendrocytes as providers of growth factors. J Neurosci Res 68:647-654.

Feng DM, Veber DF, Connolly TM, Condra C, Tang MJ, Nutt RF (1995) Development of a potent thrombin receptor ligand. J Med Chem 38:4125-4130.

Fiorucci S, Distrutti E (2002) Role of PAR2 in pain and inflammation. Trends Pharmacol Sci 23:153-155.

Gorath M, Stahnke T, Mronga T, Goldbaum O, Richter-Landsberg C (2001) Developmental changes of tau protein and mRNA in cultured rat brain oligodendrocytes. Glia 36:89-101.

Ishihara H, Connolly AJ, Zeng D, Kahn ML, Zheng YW, Timmons C, Tram T, Coughlin SR (1997) Protease-activated receptor 3 is a second thrombin receptor in humans. Nature 386:502-506.

Junge CE, Sugawara T, Mannaioni G, Alagarsamy S, Conn PJ, Brat DJ, Chan PH, Traynelis SF (2003) The contribution of proteaseactivated receptor 1 to neuronal damage caused by transient focal cerebral ischemia. Proc Natl Acad Sci USA 100:13019-13024.

Kahn ML, Hammes SR, Botka C, Coughlin SR (1998) Gene and locus structure and chromosomal localization of the protease-activated receptor gene family. J Biol Chem 273:23290-23296.

LaRosa CA, Rohrer MJ, Benoit SE, Rodino LJ, Barnard MR, Michelson $A D$ (1994) Human neutrophil cathepsin $G$ is a potent platelet activator. J Vasc Surg 19:306-318.

Lassmann H (1998) Neuropathology in multiple sclerosis: new concepts. Mult Scler 4:93-98.

Levine JM, Reynolds R, Fawcett JW (2001) The oligodendrocyte precursor cell in health and disease. Trends Neurosci 24:39-47.

Macfarlane SR, Seatter MJ, Kanke T, Hunter GD, Plevin R (2001) Proteinase-activated receptors. Pharmacol Rev 53:245-282.

Molino M, Di Lallo M, de Gaetano G, Cerletti C (1992) Intracellular $\mathrm{Ca}^{2+}$ rise in human platelets induced by polymorphonuclearleucocyte-derived cathepsin G. Biochem J 288:741-745.

Molino M, Blanchard N, Belmonte E, Tarver AP, Abrams C, Hoxie JA, Cerletti C, Brass LF (1995) Proteolysis of the human platelet and endothelial cell thrombin receptor by neutrophil-derived cathepsin G. J Biol Chem 270:11168-11175.

Moller T, Hanisch UK, Ransom BR (2000) Thrombin-induced activation of cultured rodent microglia. J Neurochem 75:1539-1547.

Moore TM, Chetham PM, Kelly JJ, Stevens T (1998) Signal transduction and regulation of lung endothelial cell permeability: interaction between calcium and cAMP. Am J Physiol 275:L203-222.

Muraro PA, Kalbus M, Afshar G, McFarland HF, Martin R (2002) T cell response to $2^{\prime}, 3^{\prime}$-cyclic nucleotide $3^{\prime}$-phosphodiesterase (CNPase) in multiple sclerosis patients. J Neuroimmunol 130:233242.

Nakanishi-Matsui M, Zheng YW, Sulciner DJ, Weiss EJ, Ludeman MJ, Coughlin SR (2000) PAR3 is a cofactor for PAR4 activation by thrombin. Nature 404:609-613.

Nishikawa H, Kawabata A, Kuroda R, Nishida M, Kawai K (2000) Characterization of protease-activated receptors in rat peritoneal mast cells. Jpn J Pharmacol 82:74-77.
Owen WG (2003) PAR-3 is a low-affinity substrate, high affinity effector of thrombin. Biochem Biophys Res Commun 305:166-168.

Pasti L, Volterra A, Pozzan T, Carmignoto G (1997) Intracellular calcium oscillations in astrocytes: a highly plastic, bidirectional form of communication between neurons and astrocytes in situ. $\mathrm{J}$ Neurosci 17:7817-7830.

Polanowska J, Krokoszynska I, Czapinska H, Watorek W, Dadlez M, Otlewski J (1998) Specificity of human cathepsin G. Biochim Biophys Acta 1386:189-198.

Reiser G, Kunzelmann U, Steinhilber G, Binmöller FJ (1994) Generation of a monoclonal antibody against the myelin protein CNP (2',3'-cyclic nucleotide $3^{\prime}$-phosphodiesterase) suitable for biochemical and for immunohistochemical investigations of CNP. Neurochem Res 19:1479-1485.

Richter-Landsberg C, Heinrich M (1996) OLN-93: a new permanent oligodendroglia cell line derived from primary rat brain glial cultures. J Neurosci Res 45:161-173.

Richter-Landsberg C, Vollgraf U (1998) Mode of cell injury and death after hydrogen peroxide exposure in cultured oligodendroglia cells. Exp Cell Res 244:218-229.

Riek-Burchardt M, Striggow F, Henrich-Noack P, Reiser G, Reymann KG (2002) Increase of prothrombin-mRNA after global cerebral ischemia in rats, with constant expression of protease nexin-1 and protease-activated receptors. Neurosci Lett 329:181-184.

Sambrano GR, Huang W, Faruqi T, Mahrus S, Craik C, Coughlin SR (2000) Cathepsin $G$ activates protease-activated receptor- 4 in human platelets. J Biol Chem 275:6819-6823.

Seeliger S, Derian CK, Vergnolle N, Bunnett NW, Nawroth R, Schmelz M, Von Der Weid PY, Buddenkotte J, Sunderkotter C, Metze D, Andrade-Gordon P, Harms E, Vestweber D, Luger TA, Steinhoff M (2003) Proinflammatory role of proteinase-activated receptor-2 in humans and mice during cutaneous inflammation in vivo. FASEB $J$ 17:1871-1885.

Selak MA (1994) Cathepsin G and thrombin: evidence for two different platelet receptors. Biochem J 297:269-275.

Smirnova IV, Citron BA, Arnold PM, Festoff BW (2001) Neuroprotective signal transduction in model motor neurons exposed to thrombin: G-protein modulation effects on neurite outgrowth, $\mathrm{Ca}^{2+}$ mobilization, and apoptosis. J Neurobiol 48:87-100.

Striggow F, Riek M, Breder J, Henrich-Noack P, Reymann KG, Reiser $G$ (2000) The protease thrombin is an endogenous mediator of hippocampal neuroprotection against ischemia at low concentrations but causes degeneration at high concentrations. Proc Natl Acad Sci USA 97:2264-2269.

Strukova SM (2001) Thrombin as a regulator of inflammation and reparative processes in tissues. Biochemistry (Mosc) 66:8-18.

Suo Z, Wu M, Ameenuddin S, Anderson HE, Zoloty JE, Citron BA, Andrade-Gordon P, Festoff BW (2002) Participation of proteaseactivated receptor-1 in thrombin-induced microglial activation. J Neurochem 80:655-666.

Totani L, Piccoli A, Pellegrini G, Di Santo A, Lorenzet R (1994) Polymorphonuclear leukocytes enhance release of growth factors by cultured endothelial cells. Arterioscler Thromb 14:125-132.

Ubl JJ, Vöhringer C, Reiser G (1998) Co-existence of two types of $\left[\mathrm{Ca}^{2+}\right]_{i}$-inducing protease-activated receptors (PAR-1 and PAR-2) in rat astrocytes and C6 glioma cells. Neuroscience 86:597-609.

Ubl JJ, Grishina ZV, Sukhomlin TK, Welte T, Sedehizade F, Reiser G (2002) Human bronchial epithelial cells express PAR-2 with different sensitivity to thermolysin. Am J Physiol Lung Cell Mol Physiol 282:L1339-1348.

Vela JM, Gonzalez B, Castellano B (1998) Understanding glial abnormalities associated with myelin deficiency in the jimpy mutant mouse. Brain Res Brain Res Rev 26:29-42.

Vergnolle N, Hollenberg MD, Sharkey KA, Wallace JL (1999a) Characterization of the inflammatory response to proteinase-activated receptor-2 (PAR2)-activating peptides in the rat paw. $\mathrm{Br} \mathrm{J}$ Pharmacol 127:1083-1090. 
Vergnolle N, Hollenberg MD, Wallace JL (1999b) Pro- and antiinflammatory actions of thrombin: a distinct role for proteinaseactivated receptor-1 (PAR1). Br J Pharmacol 126:1262-1268.

Vergnolle N, Wallace JL, Bunnett NW, Hollenberg MD (2001) Protease-activated receptors in inflammation, neuronal signaling and pain. Trends Pharmacol Sci 22:146-152.

Walker EM, Bispham JR, Hill SJ (1998) Nonselective effects of the putative phospholipase $\mathrm{C}$ inhibitor, U73122, on adenosine A1 receptor-mediated signal transduction events in Chinese hamster ovary cells. Biochem Pharmacol 56:1455-1462.

Wang H, Ubl JJ, Reiser G (2002a) Four subtypes of proteaseactivated receptors, co-expressed in rat astrocytes, evoke different physiological signaling. Glia 37:53-63.

Wang H, Ubl JJ, Stricker R, Reiser G (2002b) Thrombin (PAR-1)induced proliferation in astrocytes via MAPK involves multiple signaling pathways. Am J Physiol Cell Physiol 283:C1351-1364.
Wang H, Reiser G (2003) Thrombin signaling in the brain: the role of protease-activated receptors. Biol Chem 384:193-202.

Weksler BB, Jaffe EA, Brower MS, Cole OF (1989) Human leukocyte cathepsin $G$ and elastase specifically suppress thrombin-induced prostacyclin production in human endothelial cells. Blood 74:16271634.

Xi G, Reiser G, Keep RF (2003) The role of thrombin and thrombin receptors in ischemic, hemorrhagic and traumatic brain injury: deleterious or protective? J Neurochem 84:3-9.

Xu WF, Andersen H, Whitmore TE, Presnell SR, Yee DP, Ching A, Gilbert T, Davie EW, Foster DC (1998) Cloning and characterization of human protease-activated receptor 4. Proc Natl Acad Sci USA 95:6642-6646.

Zhao J, Li L, Wu C, He RQ (2003) Hydrolysis of fibrinogen and plasminogen by immobilized earthworm fibrinolytic enzyme II from Eisenia fetida. Int J Biol Macromol 32:165-171. 